\title{
RESEARCH
}

\section{Stem-like tumor cells involved in heterogeneous vasculogenesis in breast cancer}

\author{
Yuling Mao1,2,*, Liuqing Zhu1,3,*, Zhijian Huang3,*, Chuanghua Luo3, Ti Zhou33, Lei Li2, Guannan Wang3,4, \\ Zhonghan Yang3, Weiwei Qi1,3, Xia Yang1,3,5, Guoquan Gao ${ }^{1,3,6,7}$
}

1Program of Molecular Medicine, Affiliated Guangzhou Women and Children's Medical Center, Zhongshan School of Medicine, Sun Yat-sen University, Guangzhou, China

2Department of Reproductive Medicine Center, Key Laboratory for Reproductive Medicine of Guangdong Province, Third Affiliated Hospital of Guangzhou Medical University, Guangzhou, China

3Department of Biochemistry, Zhongshan School of Medicine, Sun Yat-sen University, Guangzhou, China

${ }^{4}$ Sun Yat-sen University Cancer Center, Guangzhou, China

${ }^{5}$ China Key Laboratory of Tropical Disease Control (Sun Yat-sen University), Ministry of Education, Guangzhou, China

${ }^{6}$ Guangdong Engineering \& Technology Research Center for Gene Manipulation and Biomacromolecular Products (Sun Yat-sen University), Guangzhou, China

${ }^{7}$ Guangdong Province Key Laboratory of Brain Function and Disease, Zhongshan School of Medicine, Sun Yat-sen University, Guangzhou, China

Correspondence should be addressed to W Qi or X Yang or G Gao: qiww3@mail.sysu.edu.cn or yangxia@mail.sysu.edu.cn or gaogq@mail.sysu.edu.cn

*(Y Mao, L Zhu and Z Huang contributed equally to this work)

\begin{abstract}
Sorafenib, a small-molecule tyrosine kinase inhibitor with antiangiogenic activity, has been used in liver cancer and kidney cancer treatments. However, clinical trials with sorafenib for breast cancer were stopped in phase III due to limited efficacy. The existence of heterogeneous vasculatures involving tumor cells, such as vessel-like structures formed by vasculogenic mimicry and mosaic vessels, and their resistance to antiangiogenic therapy are thought to be a possible reason for failure of sorafenib therapy. Nevertheless, the features and mechanism of vasculogenesis by tumor cells remain unclear. In the present study, we found that breast cancer stem-like cells (BCSLCs, $\mathrm{ALDH} 1{ }^{+}$cells) were involved in vasculogenic mimicry and mosaic vessel formation in triple-negative breast cancer tissues. Further, only ALDH1+ BCSLCs sorted from MDA-MB-231 could exhibit the tube formation and angiogenesis ability. Sorafenib could inhibit vascularization from endothelial cells rather than that from ALDH1+ cells. $\alpha$-SMA was identified as a key molecule in vascular formation of BCSLCS. Mechanistically, HIF-1 $\alpha$ enhanced the mRNA and protein levels of $\alpha$-SMA by binding to the HRE element in the promoter directly and meanwhile increased the BCSLCs population. Interestingly, pigment epithelium-derived factor (PEDF), an endogenous angiogenesis inhibitor, could inhibit both endothelial cell-derived and tumor cell-derived angiogenesis by downregulating HIF-1 $\alpha$ in breast cancer. Our finding clarified the possible reason for the poor outcome of anti-angiogenesis therapy and PEDF may have the therapeutic potential.
\end{abstract}

\section{Key Words}

- stem-like tumor cells

- heterogeneous vasculogenesis

- breast cancer

- antiangiogenic therapy https://erc bioscientifica.com https://doi.org/10.1530/ERC-19-0054
2020 Society for Endocrinology Published by Bioscientifica Ltd. Printed in Great Britain
Endocrine-Related Cancer (2020) 27, 23-39 


\section{Introduction}

Epidemiological studies have shown that breast cancer is the most common type of tumor and the leading cause of cancer-associated death in women worldwide (Torre et al. 2015). Similar to most tumors, breast cancer requires an effective microcirculation for growth, invasion, and metastasis (Folkman 2002). Targeting endothelial cells (ECs) have been a major focus of antiangiogenic therapeutics (Rayson et al. 1999). However, this strategy is encountering a bottleneck since most antiangiogenic therapeutics such as bevacizumab, endostatin and many tyrosine kinase inhibitors are not curative, likely because of common drug resistance during the late period of treatment. Sorafenib, a small-molecule tyrosine kinase inhibitor with antiangiogenic activity that targets vascular endothelial growth factor receptor (VEGFR) on ECs, is widely used in the clinical treatment of liver and kidney cancer (Wilhelm et al. 2008) and in preclinical studies of breast cancers. Unfortunately, sorafenib therapy can display limited efficacy in some cases, and phase III trials in breast cancer have been terminated (Gradishar 2012); additionally, drug resistance in liver and kidney cancer have been reported (Liang et al. 2013, Rudalska et al. 2014, Azzariti et al. 2016, Chen et al. 2016).

The growth and metastasis of solid tumors are dependent on neovascularization (Hanahan \& Weinberg 2011). For years, angiogenesis and vasculogenesis have been considered the main mechanisms of tumor neovascularization. However, there are many sources and types of tumor neovascularization, leading to heterogeneity. Several new heterogeneous vascular patterns, including vessel-like structures formed by vasculogenic mimicry, mosaic vessels, and co-opted vessels, have been discovered (Jain 1988). Recent studies have found that the presence of heterogeneous vascularity is often accompanied by poor prognosis and resistance to antiangiogenic drugs (Yu et al. 2001). These heterogeneous vessels require the direct involvement of tumor cells; however, what confers tumor cells a special ability to form blood vessels is unknown. Cancer stem cells (CSCs) are a kind of pluripotent cells that are capable of self-renewal, multilineage differentiation, and indefinite proliferation, which are critical for tumor growth and drug resistance (Singh et al. 2003, Galli et al. 2004). Recent studies have suggested that the tumor endothelium might be derived from CSCs in various tumors including glioblastoma and breast cancer (Wang et al. 2010, Tang et al. 2014). Studies have shown that glioblastoma stem-like cells (GSCs) can differentiate into ECs or pericytes to support vessel function and tumor growth (Wang et al. 2010, Cheng et al. 2013). However, the role of breast cancer stem-like cells (BCSLCs) in the formation of heterogeneous vasculature and the relationship between this role and drug resistance are still unclear. Therefore, we propose the hypothesis that tumor cells involved in heterogeneous vasculogenesis in breast cancer possess stem-like properties and that the resistance of stem-like cancer cells in heterogeneous vascularity to antiangiogenic therapy is a possible reason for treatment failure.

This present study was designed to demonstrate particular characteristics and angiogenic ability of tumor cells involved in heterogeneous vascularity in breast cancer and to determine the underlying reason and key molecule attributable for the poor curative effects of antiangiogenic therapy. The results of this study may provide new insights into the antiangiogenic treatment of breast cancer.

\section{Materials and methods}

\section{Cell lines and cell culture}

The human breast cancer cell lines MDA-MB-231 and MCF7 were were kept by our own laboratory (Hong et al. 2014). The T-47D and MDA-MB-436 cells were donated by Prof. Erwei Song. All cells have been identified by STR probes and were $100 \%$ matched cell lines that found in ATCC and DSMZ data bank. The MDA-MB-231 cell line was in the 10-20 generation and the MCF7 cell line was in the 7-15 generation during the experiment. The T-47D and MDA-MB-436 cells were in the 5-10 generation during the experiment. Both cells were cultured in DMEM (HyClone, SH30021.01B) supplemented with 10\% fetal bovine serum (FBS; Gibco BRL), $100 \mathrm{U} / \mathrm{mL}$ penicillin, and $100 \mathrm{U} / \mathrm{mL}$ streptomycin (Gibco BRL). Insulin $(0.01 \mathrm{mg} / \mathrm{mL}$, Sigma) was added to the culture medium for MCF7 cells. The cells were incubated at $37^{\circ} \mathrm{C}$ in a humidified incubator with $5 \%$ $\mathrm{CO}_{2}$ (normoxia) or $1 \% \mathrm{O}_{2}$ (hypoxia). Serum-free culture medium was used for treatments. Human umbilical vein endothelial cells (HUVECs) were isolated from umbilical veins following a previously described protocol (Jaffe et al. 1973). These cells were transferred on flasks coated with $0.2 \%$ gelatin and cultured with ECM medium containing 15\% FBS (Gibco BRL), 15 mg/L ECGS (Upstate, NY, USA) and $100 \mathrm{U} / \mathrm{mL}$ streptomycin (Gibco BRL) in an atmosphere with $5 \% \mathrm{CO}_{2}$ at $37^{\circ} \mathrm{C}$. (c) 2020 Society for Endocrinology Published by Bioscientifica Ltd. Printed in Great Britain 


\section{Animal experiments}

Female athymic mice (BALB/c nu/nu; Guangdong Medical Laboratory Animal Center) weighing 15-18 $\mathrm{g}$ were purchased at 5 weeks of age. All animals were maintained in a specific pathogen-free environment at the Laboratory Animal Center of Sun Yat-sen University. All the animal experiments were carried out with the approval of the Animal Care and Use Committee of Sun Yat-sen University (approval ID: SCXK 2015-0107). Breast cancer cells MDA-MB-231 $\left(3 \times 10^{6}\right)$ were inoculated into the mammary fat pads of mice at 6 weeks of age. When the tumor size reached $100 \mathrm{~mm}^{3}$ on day 9, the mice were randomly divided into four groups receiving the following treatments ( $n=11 /$ group). Recombinant PEDF was expressed and purified as described previously (Yang et al. 2009) and was dissolved in PBS. Intraperitoneal injection of PBS or pigment epithelium-derived factor (PEDF) $(5 \mathrm{mg} / \mathrm{kg})$ every day. These two groups are used to observe the therapeutic effect of PEDF. Sorafenib (Nexavar, $200 \mathrm{mg} /$ tablets) was dissolved in Cremophor EL/95\% ethanol (50:50; Sigma) and diluted with water before use. Lavage solvent control or sorafenib $(30 \mathrm{mg} / \mathrm{kg})$ every day to verify the efficacy of sorafenib in breast cancer. After 15 days, three mice were randomly selected from each group to examine the tumors halfway through the experiment. On day 43 after cells were injected, the experiment was terminated, and the remaining mice were killed. The maximum diameter (a) and minimum diameter (b) of the tumors were measured with calipers every 3 days to determine the tumor volume. The tumor volume was calculated by the following formula: $V=a \times b^{2} \times 0.5$. Paraffin sections $(4 \mu \mathrm{m})$ and frozen sections $(4.5 \mu \mathrm{m})$ of harvested organs were used for immunohistochemistry (IHC) and immunofluorescence (IF) assessment.

\section{Tissue immunohistochemistry and double-staining methods}

This study was approved by the Medical Ethics Committee of Sun Yat-sen University for Medical Sciences, Guangzhou. All clinical tissue sections (from the Third Affiliated Hospital and Cancer Center of Sun Yat-sen University, Guangzhou) or paraffin sections from the animals were deparaffinized by baking slides at $60^{\circ} \mathrm{C}$ for $40 \mathrm{~min}$. After deparaffinization and rehydration with graded alcohol, the slides were pretreated with $0.01 \mathrm{M}$ citrate buffer (pH 6.0) for $2 \mathrm{~min}$ at $100^{\circ} \mathrm{C}$ in an autoclave and then allowed to cool naturally. Endogenous peroxidase activities were quenched by $3 \% \mathrm{H}_{2} \mathrm{O}_{2}$ in distilled water for $30 \mathrm{~min}$, and nonspecific background was blocked in normal goat serum for $1 \mathrm{~h}$ at room temperature. Three washes were performed in PBS Tween-20 (PBST) (pH 7.2) after each step. Next, the slides were incubated with anti-CD31 antibody (1:100, Neomarkers, USA) at $4^{\circ} \mathrm{C}$ overnight in a humidified chamber. Following a brief rinse in PBST, the sections were incubated with a biotinconjugated second antibody (DAKO, K5007) for $30 \mathrm{~min}$ at room temperature and developed in DAB for $20 \mathrm{~s}$. Some sections were treated with a Periodic Acid-Schiff Staining Kit (Baso Diagnostic Inc., BA-4080A) according to the manufacturer's instructions. After rinsing in distilled water, the sections were counterstained with hematoxylin. For negative control, slides were incubated in PBS in the place of primary antibody. For animal samples, all quantifications were blindly performed in at least three randomly chosen sections from each mouse.

\section{Immunofluorescence}

Triple-negative breast cancer (TNBC) tissues and animal tissue paraffin sections were pretreated as for IHC. Frozen animal tissue sections were fixed in ice-cold $4 \%$ paraformaldehyde following permeabilization for $20 \mathrm{~min}$ with $0.01 \%$ Triton X-100 in PBS. The sections were subsequently blocked with normal donkey serum at room temperature for $1 \mathrm{~h}$. We used rabbit anti-aldehyde dehydrogenase (ALDH)-1A1 polyclonal antibody (1:100, Abcam, ab52492) or mouse anti-ALDH1 polyclonal antibody $(1: 50, \mathrm{BD}, 611194)$ to detect BCSLCs. Mouse anti-CD31 MAB (1:100, CST, 3528S) or rabbit anti-CD31 polyclonal antibody (1:100, Neomarkers) was used to detect ECs. Goat anti- $\alpha$-SMA polyclonal antibody (1:100 dilution, Abcam ab21027) or mouse anti- $\alpha$-SMA polyclonal antibody (1:200 dilution, Sigma, A2547) was used to detect pericytes. To detect cancer cells, we used rabbit anti-NuMA polyclonal antibody (1:100, Abcam, ab97585). After overnight incubation at $4^{\circ} \mathrm{C}$, the slides were incubated with appropriate fluorescent secondary antibodies (1:200 dilution in blocking buffer, $\left.1 \mathrm{~h}, 37^{\circ} \mathrm{C}\right)$. After immunolabeling, the slides were washed and then stained with 4,6-diamino-2-phenylindole (DAPI) (Sigma) for $5 \mathrm{~min}$ at room temperature. Cells were visualized under a confocal microscope (Axio Observer Z1, ZEISS).

\section{Flow cytometry and isolation of cells}

For CD44 and CD24 flow cytometry, cells were harvested using $0.25 \%$ trypsin-EDTA (Invitrogen), and single cells were resuspended in $1 \%$ FBS-PBS $\left(1 \times 10^{6}\right.$ cells/400 $\left.\mu \mathrm{L}\right)$ 
containing FITC-conjugated anti-CD44 (BD Biosciences) and PE-conjugated anti-CD24 (BD Biosciences) antibodies. Subsequently, the cells and their respective controls were incubated on ice in the dark for $45 \mathrm{~min}$. After incubation, the stained cells were washed with PBS and suspended in $500 \mu \mathrm{l} 1 \%$ FBS-PBS and detected by a flow cytometer (Gallios, Beckman Coulter Inc.). Kaluza software (Beckman Coulter Inc.) was used for data analysis.

The ALDEFLUOR assay was performed as described by the manufacturer (Stem Cell Technologies, Vancouver, British Columbia, Canada). Briefly, cells were harvested and resuspended in assay buffer at $1 \times 10^{6}$ cells $/ \mathrm{mL}$ and added to a tube containing activated ALDEFLUOR substrate BODIPY amino acetaldehyde (BAAA). Half of each sample was transferred to a tube containing $5 \mu \mathrm{L} / 500 \mu \mathrm{L}$ ALDH1 inhibitor diethylamino benzaldehyde (DEAB). The samples were incubated at $37^{\circ} \mathrm{C}$ for $45 \mathrm{~min}$. The cells were resuspended in assay buffer and assayed with a FACS Canto II flow cytometer. ALDH1 bright region was based on the control DEAB sample that was gated to represent less than 0.5 percent of cells. Based on cell-surface marker phenotype and ALDH1 activity, MDA-MB-231 cells were isolated into ALDH1+ and ALDH1- subsets by a FACS Vantage/Diva cell sorter (BD Biosciences). The sorted cells were immediately used for functional in vitro experiments and Western blotting.

\section{Tube formation assays}

Matrigel (BD Biosciences, San Jose, CA, USA) was thawed at $4^{\circ} \mathrm{C}$ overnight, and $100 \mu \mathrm{L}$ of Matrigel was evenly added to each well of a pre-cooled 24 -well plate. The plate was incubated at $37^{\circ} \mathrm{C}$ for $30 \mathrm{~min}$. Cells $\left(2 \times 10^{5}\right)$ in $1 \mathrm{~mL}$ suspension were added on top of the matrix in 24-well plates and incubated at $37^{\circ} \mathrm{C}$ for varying durations. For co-culture experiments, different cells and culture medium were divided in half. Wells were imaged using an inverted fluorescence microscope (Olympus $1 \times 71$ ).

\section{Western blot analysis}

Samples for Western blot analysis were prepared as follows: Lysates from cultured cells were prepared using a 1× SDS buffer. Protein concentrations were determined using a Bio-Rad DC protein assay kit (Bio-Rad Laboratories) according to the manufacturer's protocol. Lysates with equal amounts of protein (50 ng) were loaded and separated by $10 \%$ SDS-PAGE. Proteins were transferred to PVDF membranes (Millipore Corp.) for $3 \mathrm{~h}$. After blocking with 7\% milk in Tris-buffered saline Tween-20 (TBST) for $1.5 \mathrm{~h}$, the membranes were incubated overnight at $4^{\circ} \mathrm{C}$ with primary antibodies against HIF-1 $\alpha$ (1:1000, BD), CD44 (1:4000, Proteintech, 15675-1-AP), ALDH1 (1:1000, Abcam, ab52492), $\alpha$-SMA (1:1000, Sigma, A2547), PEDF (1:1000, Millipore, MAB1059), PDGFR (1:1000, CST, 3169S), DESMIN (1:1000, Santa Cruz, sc-365130), NG2 (1:1000, Millipore, MAB5384), VE-cadherin (1:1000, Abcam, ab33168), or CD31 (1:1000, Neomarkers). The blots were washed three times with $1 \times$ TBST and incubated with their respective secondary antibodies for $4 \mathrm{~h}$ at $4^{\circ} \mathrm{C}$. The membranes were again washed with TBST, and then immunoblots were developed with ECL reagents from Pierce. To confirm equal sample loading, we probed the blots with an antibody specific to $\beta$-actin (1:5000, Sigma).

\section{SiRNA transfection}

For knockdown experiments, siRNA oligonucleotides matching selected regions of $\alpha$-SMA sequence and control siRNA were purchased from RiboBio Company (Shanghai, China). Transfection was performed at approximately $60 \%$ confluency using HiPerfect reagent (Qiagen) with siRNA oligonucleotides at a final concentration of $100 \mathrm{nM}$ according to the manufacturer's instructions. Briefly, siRNAs and transfection reagent diluted in OptiMEM (Invitrogen) were mixed and incubated at room temperature for $20 \mathrm{~min}$. Next, the siRNA-reagent complex was added to cells in $1.5 \mathrm{~mL}$ (six-well plate) serum-free medium. The knockdown of protein expression was confirmed by Western blotting $36 \mathrm{~h}$ later.

\section{Chromatin immunoprecipitation (ChIP) assay}

Hypoxia-inducible factor $1 \alpha$ (HIF-1 $\alpha)$ is a transcription factor that can bind to hypoxia-responsive elements (HREs; 5'-A/G CGT G/CC-3') to regulate the expression of its target genes. Several predicted HREs are located upstream of the ACTA2 promoter, and ChIP assays were carried out to investigate whether HIF- $1 \alpha$ protein binds to these HREs under hypoxic conditions. To this end, we used a ChIP assay kit (Millipore Corp Cat. No. 17-10461) essentially against it according to the manufacturer's specifications. MDA-MD-231 cells were cultured with $1 \%$ oxygen at $37^{\circ} \mathrm{C}$ for $48 \mathrm{~h}$ and fixed with $1 \%$ formaldehyde for $15 \mathrm{~min}$. The cross-linking reaction was quenched with glycine. Cell lysates were then sonicated to shear cross-linked DNA to 200- to 1000-bp fragments. Precleared lysates were subjected to overnight (c) 2020 Society for Endocrinology Published by Bioscientifica Ltd. Printed in Great Britain 
immunoprecipitation (IP) of cross-linked protein/DNA with rabbit anti-HIF- $1 \alpha$ antibody $(10 \mathrm{~g} / \mathrm{mL})$ (14179S, Cell Signaling Technologies (CST)) or normal rabbit IgG (10 $\mathrm{g} / \mathrm{mL}$ ) (negative control). ChIP DNA enrichment was evaluated through quantitative real-time PCR (qRT-PCR) using the following primers: ACTA2 first set of primer sequences are 5'-CGGGAGCCAGTCTCCAACGC-3' and 5'-AGCTGGAGCTGCTTCACAGG-3'. ACTA2 second set of primer sequences are 5'-GCAAGTCCTCCAGCGTTCTG-3' and 5'-GGGGATAGGCAAAGTGGGGC-3'. The positive control VEGF primer sequences are 5'-CGCACG TAACCTCACTTTCC-3' and 5'-CAATGAAGGGGAAGC TCGAC-3'. Pre-immunoprecipitated samples (input) were also included as controls for PCR.

\section{Luciferase reporter assay}

To verify the binding sites for HIF-1 $\alpha$ protein on the ACTA2 gene promoter, we amplified the sequences of the ACTA2 gene promoter by PCR from MDA-MD-231 cells. The amplified DNA sequences were inserted into the pGL3-basic vector (OBIO, Shanghai, China) to generate ACTA2 promoter luciferase reporter vectors. Mutated ACTA2 promoter luciferase reporter vectors were generated using standard PCR techniques to validate the following predicted binding site on the ACTA2 promoter: 5'-CGCCTCCCGCAGCAGCCCGCCGCTCCCAGGTG CCCGCGTGCGCCGCTGCC-3'. For luciferase reporter assays, MDA-MD-231 cells were seeded in 96-well plates prior to transfection. Then, $0.2 \mu \mathrm{g}$ of ACTA2 promoter reporter construct was transfected into cells together with $0.02 \mu \mathrm{g}$ Renilla luciferase reported construct, and $0.2 \mu \mathrm{g}$ indicated si-HIF- $1 \alpha$ plasmids following incubation in $1 \%$ oxygen at $37^{\circ} \mathrm{C}$ for $48 \mathrm{~h}$. Firefly luciferase activity and Renilla luciferase activity were measured using the Dual-Luciferase Reporter system (Promega) using a luminometer (Berthold Centro LB 960, Germany) according to manufacturer's instructions. Luciferase activities were normalized to that of Renilla luciferase, and a negative control vector, pGL3-basic, was added at identical amount to normalize the expression as fold increase in relative light units.

\section{Statistical analysis}

Student's $t$-tests were used for comparisons between two groups. SPSS version 13.0 software was used for all analyses. $P<0.05$ was considered statistically significant. Kaplan-Meier actuarial survival curves were used for survival analyses.

\section{Results}

Sorafenib has no effect on heterogeneous vascularity formed by breast cancer cells in vivo or in vitro

Sorafenib is an oral multikinase inhibitor, approved for antiangiogenic treatment of advanced renal cell carcinoma and hepatocellular carcinoma (HCC) targeted at ECs (Llovet et al. 2008, Yang et al. 2009). However, studies have found that long-term treatment with sorafenib can even enhance the metastatic potential of HCC, non-small-cell lung cancer (Adjei et al. 2011), and renal cell carcinoma (Hutson et al. 2010). In breast cancer, a phase III clinical trial with sorafenib was terminated because of limited efficacy. To identify the possible reasons for the poor therapeutic role of sorafenib in breast cancer, we performed several in vivo and in vitro experiments.

In our xenograft model, tumor size in the sorafenib group was significantly smaller than that in the control groups on day 24, but there was no difference on day 43 (Supplementary Fig. 1B and C, see section on supplementary materials given at the end of this article). Four mice were euthanized in the control group, two on day 38 , one on day 39 and one on day 41 . Three mice were euthanized in the sorafenib group, one on day 39 , one on day 40 and one on day 41 . We found that sorafenib did not improve overall survival (Supplementary Fig. 1D).

There are many sources and types of tumor neovascularization, leading to heterogeneity. Several new heterogeneous vascular patterns, including vessellike structures formed by vasculogenic mimicry, mosaic vessels, and co-opted vessels, have been discovered (Jain 1988). Vasculogenic mimicry is a phenomenon by which aggressive tumor cells form vascular structures to obtain nutrients without the participation of ECs (Basu et al. 2006). Moreover, mosaic tumor vessels are known as transitional heterogeneous vascularity made of both ECs and tumor cells (di Tomaso et al. 2005). Heterogeneous vascularity was detected by staining the tumor specimens with anti-CD31 antibody to detect ECs and periodic acidSchiff (PAS) to detect glycogen. Notably, microvascular density (MVD, CD31+) was dramatically decreased in the sorafenib-treated group at all time points, and compared to that in mice in the control group vasculogenic mimicry $\left(\mathrm{CD} 31-/ \mathrm{PAS}^{+}\right)$was observed in mice in the sorafenib group at a later stage (Supplementary Fig. $1 \mathrm{E}$ and F). We speculated that at later stages, vasculogenic mimicry, a type of heterogeneous vascularity constituted by aggressive tumor cells form vascular structures to obtain 
nutrients without the participation of ECs $\left(\mathrm{CD} 31-/ \mathrm{PAS}^{+}\right)$ (Basu et al. 2006), gives rise to predominant vascular structures in tumors (full of blood cells) and that sorafenib is ineffective against this type of blood vessels.

Finally, to verify our in vivo observations with sorafenib, we performed 3D in vitro experiments. In agreement with our previous study in vivo, sorafenib suppressed tubular network formed by HUVECs in a concentration-dependent manner but was unable to affect the structures formed by MDA-MB-231 cells (Supplementary Fig. 1G).

These results suggested that sorafenib can suppress vascular structures composed of ECs rather than those formed by vasculogenic mimicry of breast cancer cells, and this may be the likely cause of the lack of efficacy of sorafenib in breast cancer.

\section{ALDH1+ breast cancer cells exhibit tube-forming ability}

Formation of capillary-like structures in Matrigel is a commonly used functional test for tube formation. To verify whether BCSLCs can generate heterogeneous vasculature in vitro, we initially chose two different breast cancer cell lines, namely, MCF7 and MDA-MB-231, to investigate their tube-forming ability. Among these cell lines, only MDA-MB-231, a TNBC cell line, could form typical vessel-like structures under the same 3D culture conditions. In contrast, MCF7 cells, which are less invasive, could not form vascular networks in vitro (Fig. 1A). Moreover, flow cytometry was used to assess the expression of BCSLC markers in MCF7 and MDA-MB-231 cells. As illustrated in Fig. 1B and C, the proportion of $\mathrm{CD} 44^{+} \mathrm{CD} 24^{-}$and $\mathrm{ALDH} 1^{+}$cells were significantly higher in MDA-MB-231 cells than in MCF7 cells. To further clarify the role of BCSLCs in heterogeneous vasculogenesis in vitro, we isolated ALDH1+ and ALDH1- MDA-MB-231 cells by a FACS sorter and cultured them in a 3D matrix to examine VM formation for 3 days. Interestingly, we found that only BCSLCs, ALDH1+ MDA-MB-231 cells, exhibited tube-forming ability in vitro, while ALDH1- cells lacked this ability (Fig. 1D). The similar results were confirmed in T-47D and MDA-MB-456 cell lines (Supplementary Fig. 2). Furthermore, we co-cultured BCSLCs with HUVECs and found that BCSLCs could form more capillarylike structures in Matrigel than ALDH1- MDA-MB-231 cells, and the co-cultures led to the formation of mosaic vessels made of both HUVECs and tumor cells (di Tomaso et al. 2005) in vitro (Supplementary Fig. 3).
These results indicated that BCSLCs directly participated in heterogeneous vasculogenesis (both $\mathrm{VM}$ and mosaic vessels) in breast cancer. However, the mechanisms underlying the ability of BCSLCs to mimic a capillary wall with ECs are not yet clear.

\section{$\alpha$-SMA is a critical molecule in tube formation by BCSLCS}

It is known that highly aggressive cancer cells can initiate the formation of vascular channels by mimicking the behavior of ECs (Du et al. 2014). We wondered whether BCSLCs could do the same. To this end, we performed molecular analysis of specific vascular markers using Western blotting. A high level of expression of pericyte marker $\alpha$-SMA was observed in ALDH1+ MDA-MB-231 cells capable of tube formation. However, none of the breast cancer cells expressed EC markers (Fig. 2A). However, $\alpha$-SMA is not only a pericyte marker but also a marker of epithelial-to-mesenchymal transition (EMT). Latest research indicates that EMT endows cancer cells with pericyte properties and is indispensable for vascular stabilization and sustained tumor growth (Shenoy et al. 2016). To understand whether EMT enables BCSLCs to participate in heterogeneous vasculogenesis in tumors, we also examined several EMT markers in BCSLCs by Western blotting. Interestingly, $\alpha$-SMA was the only observed upregulated mesenchymal marker in ALDH1+ MDA-MB-231 cells, although both ALDH1+ and ALDH1- cells exhibited EMT (Fig. 2B). In other words, not all cells undergoing EMT, such as ALDH1- cells, can form tubular structures, and only stem-like property enables tumor cells to form tube-like structures. Furthermore, to explore whether EMT and the pericyte marker $\alpha$-SMA play a critical role during tube formation, we silenced the expression of $\alpha$-SMA protein in MDA-MB-231 cells using siRNA technology. The reduction in $\alpha$-SMA expression was confirmed using Western blot analysis (Fig. 2C). Observably, the tube-forming ability of MDA-MB-231 was inhibited (Fig. 2C). Moreover, the tube-forming capacity was higher in $\alpha$-SMA-transfected MCF7 cells than in vector-transfected cells (Fig. 2D). Furthermore, the tubular structures were closer to normal blood vessels and more stable in MDA-MB-231 cells co-cultured with HUVECs than in cells cultured alone (Fig. 2E and F). Thus, we believe that $\alpha$-SMA is a critical functional molecule during tube formation by BCSLCs. This important ability of $\alpha$-SMA in tube formation was also confirmed by in vitro experiment in the T-47D and MDA-MB-456 cell lines (Supplementary Fig. 4). (c) 2020 Society for Endocrinology Published by Bioscientifica Ltd. Printed in Great Britain 
A
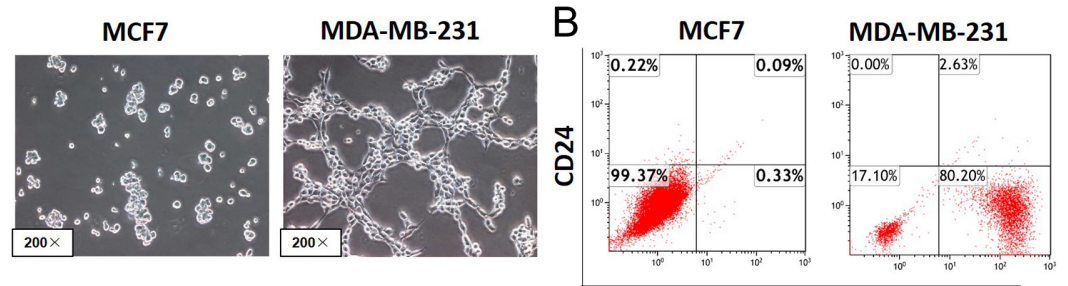

MDA-MB-231

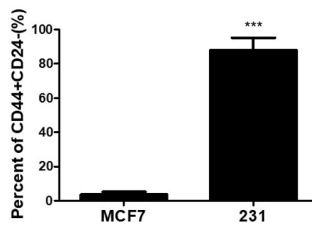

CD44

C
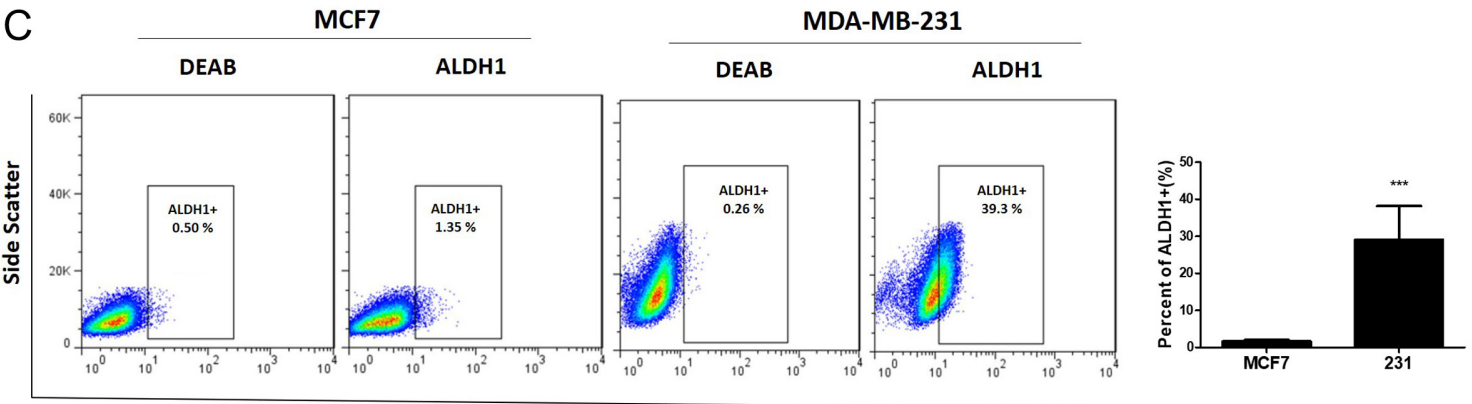

FITC

D
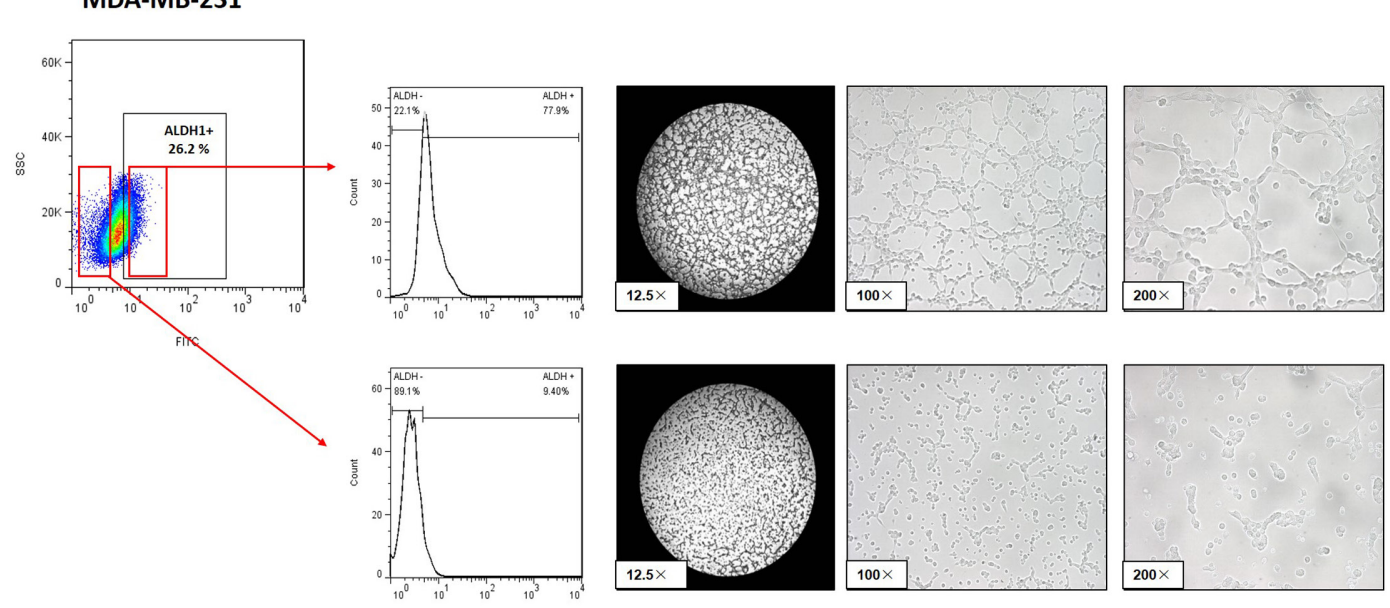

Figure 1

ALDH1+ MDA-MB-231 cells exhibit tube-forming ability. (A) Matrigel tube formation assays were used to detect the ability of tube formation in a TNBC cell line MDA-MB-231 and poorly invasive cell line MCF7. (Original magnification, $\times 200$ ). (B) CD44+CD24- stem-like cells were detected by flow cytometry. The corresponding quantified data by FACS analysis $(n=3)$. (C) ALDH1 ${ }^{+}$stem-like cells labeled with the ALDEFLUOR ${ }^{\mathrm{TM}}$ assay kit (Stem Cell). The gate for ALDH1 ${ }^{+}$ cells was determined in relation to the DEAB control (first column DEAB') and showed the brightly fluorescent ALDH1 population versus the side scatter population. The number shown in each panel reflects the percentage of ALDH1+ MDA-MB-231 and MCF7 cells. The corresponding quantified data by FACS analysis $(n=3)$. (D) FACS was used to isolate ALDH1+ and ALDH1- subsets from MDA-MB-231 cells for tube formation assays over 3 days. The expression of BCSLC marker ALDH1 was identified before tube formation assays. Representative micrographs with different magnification showing the formation of capillary-like structures in Matrigel. A full colour version of this figure is available at https://doi.org/10.1530/ERC-19-0054.

\section{Heterogeneous vascularity is found in TNBC specimens}

Vasculogenic mimicry is a phenomenon by which aggressive tumor cells form vascular structures to obtain nutrients without the participation of ECs (Basu et al. 2006). It is a newly defined type of tumor vasculature discovered by Maniotis et al. (1999). After initial observations in melanoma (Hendrix et al. 2003), evidence for vasculogenic mimicry has been discovered in other cancers, including glioblastoma (El Hallani et al. 2010), breast cancer (Shirakawa et al. 2001), HCC (Sun et al. 2010), and prostate cancer (Sharma et al. 2002). Vasculogenic mimicry is negatively correlated with disease prognosis. Moreover, mosaic tumor vessels are known as transitional heterogeneous vascularity made of both ECs and tumor cells (di Tomaso et al. 2005). Although few in number, these two types of heterogeneous vascularity composed 
A

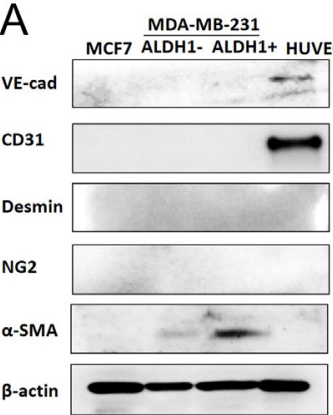

B

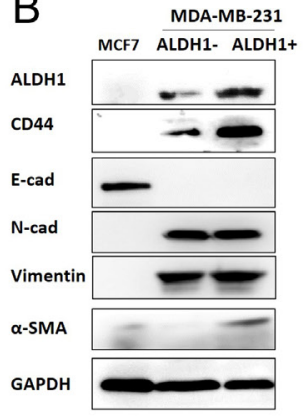

C

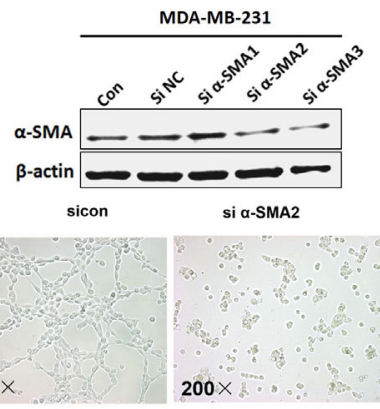

D

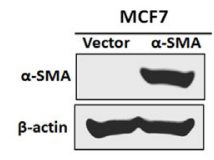

vector

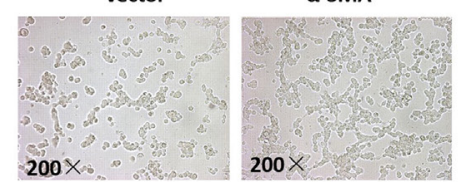

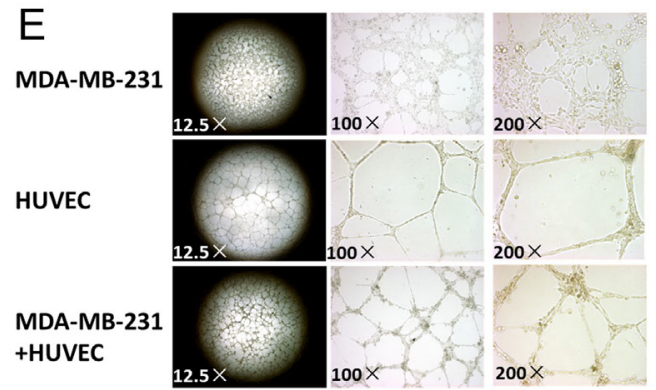

F MDA-MB-231

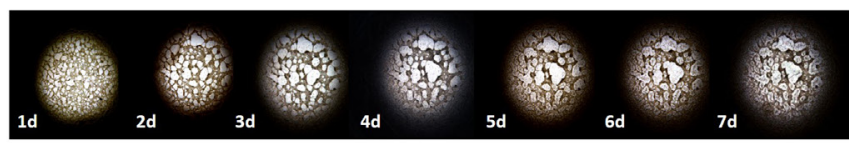

HUVEC

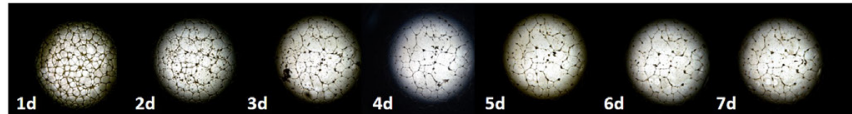

MDA-MB-231 + HUVEC

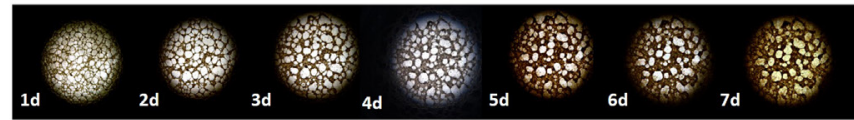

Figure 2

$\alpha$-SMA is a critical molecule in tube formation by cancer cells. (A) Western blot analysis of vascular markers (A) and EMT markers (B) expressed by breast cancer cells MDA-MB-231 and MCF7 ( $\beta$-actin, control protein). HUVECs were used as a positive control for EC markers. (C) siRNA interference effect was validated by Western blotting. siRNA interference technology was used to knock down $\alpha$-SMA in MDA-MB-231 cells before the formation of capillary-like structures in Matrigel. (D) Matrigel tube formation assay in breast cancer MCF7 cells transiently transfected with vector/ $\alpha$-SMA for 24 h. (E) Representative micrographs showing the formation of capillary-like structures in Matrigel formed by MDA-MB-231 cells and HUVECs and their co-cultures. (F) Stability of these three tubular structures. A full colour version of this figure is available at https://doi.org/10.1530/ERC-19-0054.

of tumor cells are thought to be possible reasons for the poor curative effects of antiangiogenic therapy. CSCs are similar in the sense that they are few in number but can drive tumor progression. Thus, we speculated that not all tumor cells can form tube-like structures and that only CSCs have the ability to form tubes. Therefore, we examined 40 surgically resected breast cancer specimens for evidence of vasculogenic mimicry and mosaic vessels using IF. We used anti-CD31 antibody to identify ECs, anti- $\alpha$-SMA antibody to detect pericytes and anti-ALDH1 antibody to identify BCSLCs.

In breast cancer, $\mathrm{CD} 44^{+} / \mathrm{CD} 24^{-}$and $\mathrm{ALDH} 1^{+}$cells have been reported as tumor-initiating cells (Al-Hajj et al. 2003, Ginestier et al. 2007, Nakanishi et al. 2010). ALDH1 is a kind of intracellular enzyme that can oxidize aldehyde into acetic acid; it is highly expressed in a variety of CSCs and is closely correlated with poor prognosis in breast cancer (Ginestier et al. 2007). There are reports that ALDH1 is a better clinical indicator for relapse of invasive ductal breast cancer than the $\mathrm{CD} 44^{+} / \mathrm{CD} 24^{-}$phenotype (Zhong et al. 2014). Therefore, we selected ALDH1 as a marker for BCSLCs to determine the location of BCSLCs and to investigate their relationship with heterogeneous vascularity in breast cancer.
We found that most vessels in breast cancer specimens were adorned with $\mathrm{CD} 31^{+}$cells with typical pericytic location $\left(\alpha-\mathrm{SMA}^{+} / \mathrm{CD} 31^{+} / \mathrm{ALDH}^{-}\right)$which is known as angiogenesis in cancer (Fig. 3A). In TNBC specimens, we also found that some vessels were composed of BCSLCs, stained by ALDH1 together with $\alpha$-SMA or CD31. We considered this kind of vessels as mosaic tumor vessels (Fig. 3A). Surprisingly, in a few TNBC specimens (5\%, two specimens), some cancer cells that highly expressed ALDH1 and $\alpha$-SMA but were negative for CD31 organized themselves into vessel-like structures similar to vasculogenic mimicry ( $\left.\alpha-\mathrm{SMA}^{+} / \mathrm{ALDH}^{+}{ }^{+} \mathrm{CD}^{-} 1^{-}\right)$(Fig. $\left.3 \mathrm{~A}\right)$, and these vessels were histologically different from breast ducts (Supplementary Fig. 5). These results indicated the presence of heterogeneous vascularity in breast cancer tissues and showed that the cells involved in these vessels were BCSLCs rather than normal tumor cells.

\section{MDA-MB-231 expressing $\alpha$-SMA participate in the formation of various heterogeneous vascularity in xenograft models}

Our previous results confirmed the presence of heterogeneous vascularity in TNBC specimens (Fig. 3)
(C) 2020 Society for Endocrinology Published by Bioscientifica Ltd. Printed in Great Britain 
A

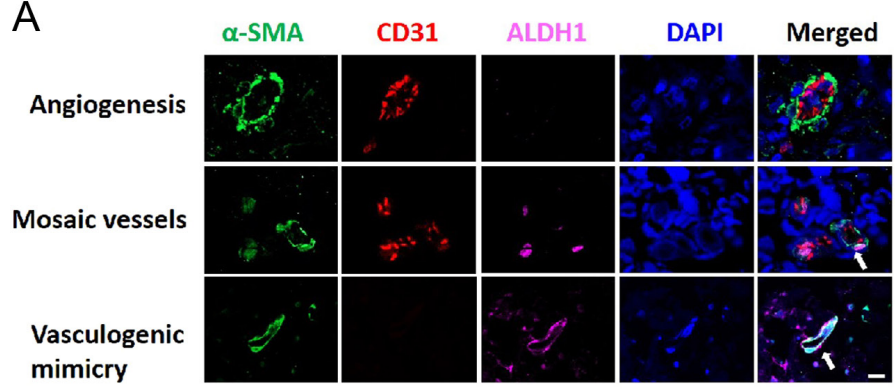

B
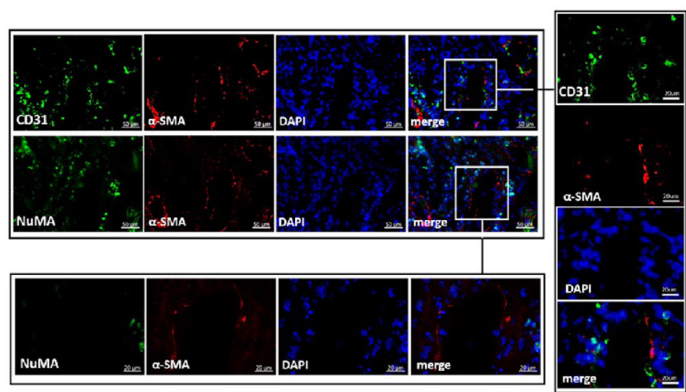

C
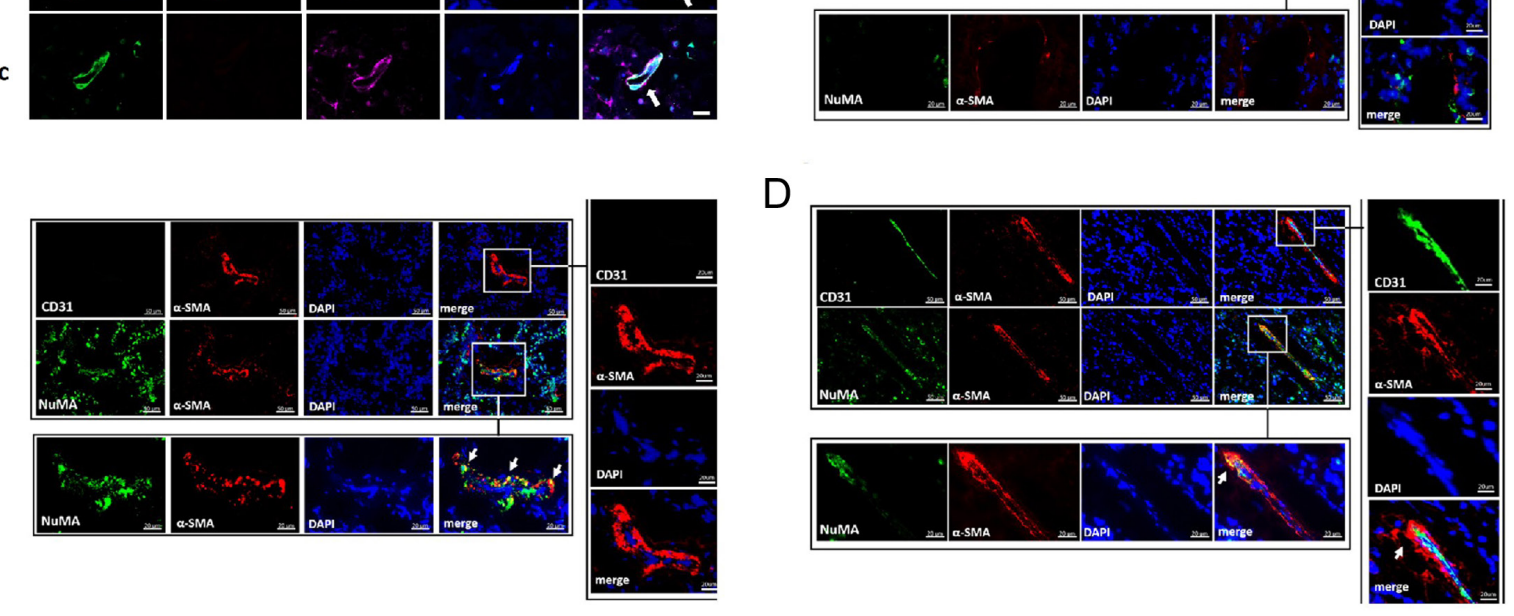

\section{Figure 3}

MDA-MB-231 cells expressing $\alpha$-SMA participate in the composition of various heterogeneous vasculatures in vivo. (A) IF staining of a pericyte marker $\alpha$-SMA (green), an EC marker CD31 (red) and a BCSLC marker ALDH1 (pink) in TNBC. Nuclei were stained with DAPI (blue); the arrow points to the corresponding vessel. Scale bar: $20 \mu \mathrm{m}$. (B, C and D) IF staining of CD31 (an EC marker) and $\alpha$-SMA (a pericyte marker) in xenografts. Nuclei were stained with DAPI. NuMA was used for identifying human breast cancer cells. Arrows show heterogeneous vascularity (NuMA ${ }^{+}$and $\alpha-\mathrm{SMA}^{+}$).

and the important functional role of $\alpha$-SMA, an EMT and pericyte marker, in the formation of capillarylike structures (Fig. 2). Next, we performed IF to verify different types of microcirculation patterns in xenografts in nude mice.

Most tumor vessels in the xenografts were adorned with $\mathrm{CD}^{+} 1^{+}$cells with typical pericytic ( $\alpha-\mathrm{SMA}^{+}$cells) location and morphology of vessels (Fig. 3B). These $\alpha-\mathrm{SMA}^{+}$ cells were completely negative for the human cell-specific nuclear antigen NuMA, confirming that these pericytes were derived from the nude mice. As illustrated in Fig. 3C, in vessels that were only composed of $\alpha-\mathrm{SMA}^{+}$cells, the $\alpha-\mathrm{SMA}^{+}$cells also expressed NuMA, indicating that these cells were derived from the human MDA-MB-231 cells. We called the process of formation of capillary-like structures vasculogenic mimicry. The third kind of vessels (Fig. 3D) are the mosaic vessels. Tumor vessels were adorned with $\alpha-\mathrm{SMA}^{+}$cells that were mostly derived from nude mice $\left(\mathrm{NuMA}^{-}\right)$, but a fraction of cells was derived from human MDA-MB-231 (NuMA+).

Collectively, these data provide direct evidence that MDA-MB-231 cells expressing $\alpha$-SMA participate in tube formation in vivo. However, why the TNBC cell line MDA-MB-231 has a high proportion of BCSLCs and highly express $\alpha$-SMA are not yet known.

\section{HIF-1 $\alpha$ upregulates $\alpha$-SMA transcription by binding to the HRE on the ACTA2 promoter}

To verify the regulatory mechanism of $\alpha$-SMA, we assessed the expression of HIF- $1 \alpha$ and $\alpha$-SMA in breast cancer cell lines by Western blot analysis. A high level of expression was found in MDA-MB-231 cells, with absent or very low expression in MCF7 cells (Fig. 4A). Moreover, we inhibited the expression of the HIF- $1 \alpha$ protein in MDA-MB-231 cells using 2-methoxyestradiol (2ME2) which is a smallmolecule inhibitor of HIF-1. Both the mRNA and protein levels of ACTA2 (the gene encoding $\alpha$-SMA) significantly decreased upon 2ME2 treatment (Fig. 4D and E). In contrast, $\alpha$-SMA protein and mRNA expression was significantly increased in MCF7 cells cultured under hypoxia (Fig. 4B and C).

Since HIF- $1 \alpha$ is a transcription factor that can bind to HREs (5'-A/G CGT G/CC-3') to regulate the expression of its target genes, we speculated that the ACTA2 promoter is directly regulated by HIF- $1 \alpha$. To this end, we first predicted several HREs located upstream of the ACTA2 promoter using a series of bioinformatics software. Next, we carried out ChIP assays to investigate whether HIF- $1 \alpha$ proteins bind to these HREs in MDA-MB-231 cells after hypoxia conditioning. ChIP DNA enrichment was (c) 2020 Society for Endocrinology Published by Bioscientifica Ltd. Printed in Great Britain 

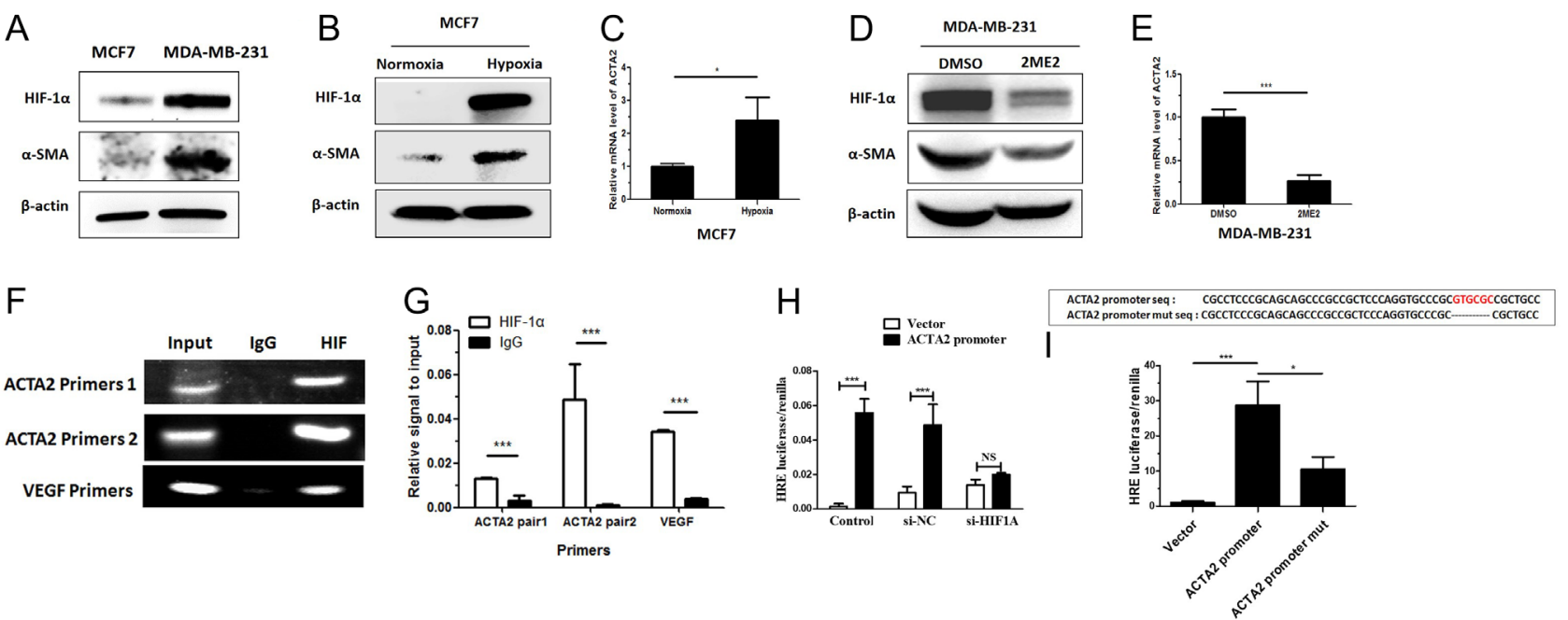

\section{Figure 4}

HIF-1 $\alpha$ regulates the levels of $\alpha$-SMA by binding to the HRE on the promoter. (A) $\alpha$-SMA and HIF-1 $\alpha$ expression in MCF7 and MDA-MB-231 cells by Western blot analysis ( $\beta$-actin, control protein). Western blot and RT-PCR analysis for $\alpha$-SMA expression in MCF7 cells after hypoxic conditioning for $24 \mathrm{~h}$ (B and C) and in MDA-MB-231 cells treated with 2ME2 ( $D$ and E). ( $F$ and G) ChIP-PCR validation of the increase in $\alpha$-SMA expression in MDA-MB-231 cells after hypoxia conditioning. $(\mathrm{H})$ Luciferase activity of the ACTA2 promoter after the inhibition of HIF-1 $\alpha$ in MDA-MB-231 cells under hypoxia was determined as specified in the Methods section. (I) The luciferase activity of the wild-type and mutated ACTA2 promoter reporter in MDA-MB-231 cells under hypoxia (Mean \pm S.D., $* P<0.05$, $* \star \star P<0.001$ compared with untreated control). A full colour version of this figure is available at https://doi.org/10.1530/ ERC-19-0054.

evaluated through qRT-PCR, which indicated the binding between HIF- $1 \alpha$ protein and the ACTA2 promoter after $48 \mathrm{~h}$ of hypoxia conditioning (Fig. 4F and G). ACTA2 promoter luciferase reporter vectors were generated by OBIO company (Shanghai, China) and co-transfected into MDA-MB-231 cells with indicated si-HIF-1 plasmids or neutral control vectors. Luciferase activity was restored by si-HIF-1 plasmids in the presence of $1 \%$ oxygen at $37^{\circ} \mathrm{C}$ for $48 \mathrm{~h}$ (Fig. $4 \mathrm{H}$ ). Moreover, to verify the binding sites for HIF- $1 \alpha$ on the ACTA2 gene promoter, we mutated the following predicted binding site on the ACTA2 promoter: 5-CGCCTCCCGCAGCAGCCCGCCGCTCCCAGGTGC CCGCGTGCGCCGCTGCC-3 to generate a mutated ACTA2 promoter the fluorescence could also be restored by the mutation promoter report vectors (Fig. 4I). These results indicated that HIF- $1 \alpha$ regulates $\alpha$-SMA by directly binding to the HRE on its promoter.

\section{Hypoxia induces heterogeneous vasculogenesis by increasing the proportion of stem-like cells}

Oxygen is very important for tumor angiogenesis and metastasis and cell proliferation and apoptosis (Zhong et al. 1999). HIF-1 $\alpha$ is the major transcription factor involved in the adaptive response to hypoxia. It combined with a constitutively expressed $\beta$-subunit (HIF-1 $\beta)$ to compose HIF-1 transcription factors.
HIF- $1 \alpha$ protein is crucial factor for vasculogenic mimicry in several tumor types (Sun et al. 2007, 2012, Du et al. 2014) and increases cancer stemness (Takubo et al. 2010, Lu et al. 2015). Hence, we hypothesized that sorafenib can exacerbate hypoxia to increase the proportion of BCSLCs, which results in more heterogeneous vascularity and drug resistance.

First, we assessed the mRNA and protein expression level of HIF- $1 \alpha$ in MDA-MB-231 and MCF7 cells. HIF- $1 \alpha$ expression was high in MDA-MB-231 cells; in contrast, the level of HIF-1 $\alpha$ in MCF7 cells was significantly lower (Fig. 5A and B). The functional role of HIF-1 $\alpha$ in the formation of vessel-like tubes in vitro was determined by treatment with of MDA-MB-231 and MDA-MB-436 cells with 2ME2 (a selective HIF-1 $\alpha$ inhibitor) and hypoxia conditioning in MCF7 and T-47D cells. Compared with the controls, 2ME2 significantly reduced the proportion of stem-like cells (Fig. 5C, E and G) and inhibited vascular channel formation (Fig. 5I) in MDA-MB-231 cells as well as MDA-MB-436 cells (Supplementary Fig. 6C and D). In addition, after hypoxia conditioning, the proportion of the stem-like cells increased significantly (Fig. 5D, F and $\mathrm{H}$ ) in MCF7 cells and resulted in the formation of similar vessel-like structures (Fig. 5J). The similar results were confirmed in T-47D (Supplementary Fig. 6A and B). Therefore, hypoxia promotes the expression of HIF- $1 \alpha$, which is a critical mediator of tube formation by (c) 2020 Society for Endocrinology Published by Bioscientifica Ltd. Printed in Great Britain 
A
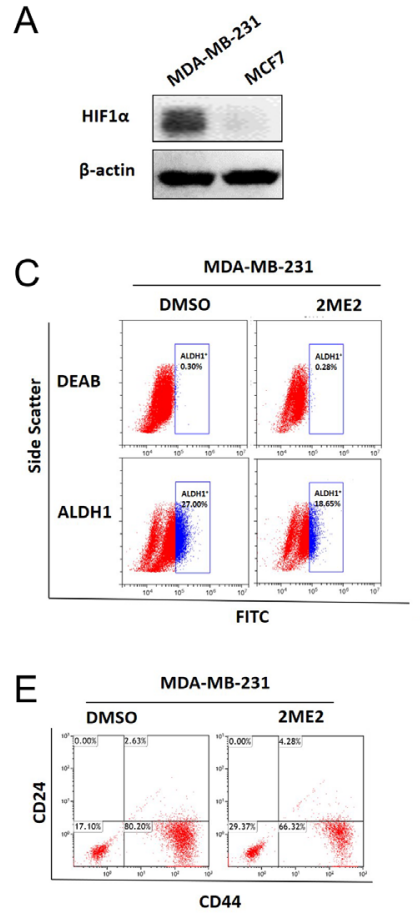

G

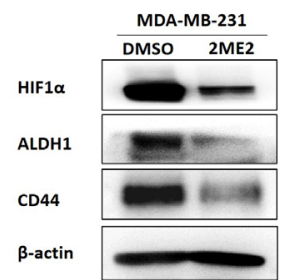

I

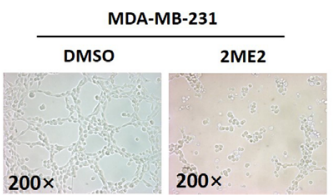

B
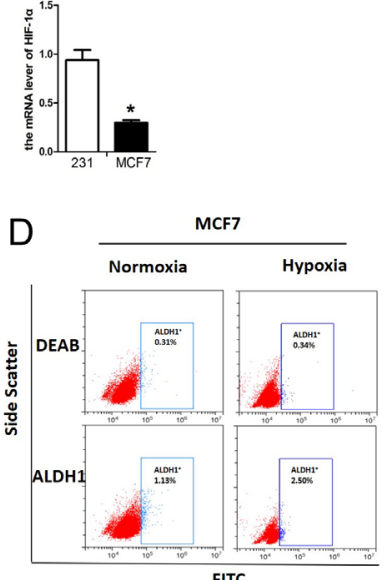

$\mathrm{F}$

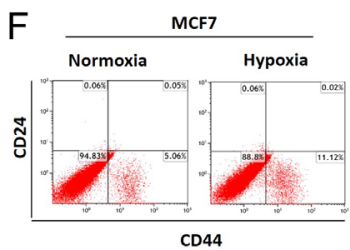

$\mathrm{H}$

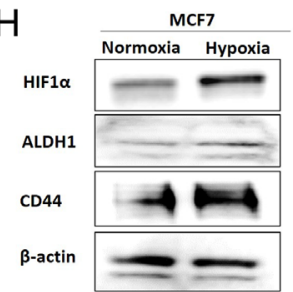

$\mathrm{J}$

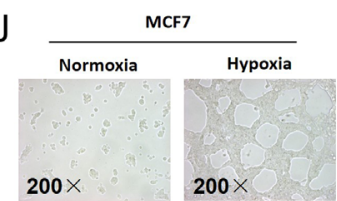

Figure 5

Hypoxia induces channel formation by increasing the proportion of stem-like cells. (A and B) HIF-1 $\alpha$ mRNA and protein expression level in MDA-MB-231 and MCF7 cells ( $* P<0.05)$. (C, D, E and F) The proportion of stem cells detected by flow cytometry after the addition of the HIF-1 $\alpha$ inhibitor 2ME2 to MDA-MB-231 cells and hypoxic conditioning in MCF7 cells. ( $G$ and $H$ ) Western blotting was used to examine the protein levels of CD44 after the addition of 2ME2 (DMSO was used as a negative control) in MDA-MB-231 cells and hypoxic conditioning in MCF7 cells. (I and J) Variation in tube-forming ability after the addition of the HIF-1 $\alpha$ inhibitor 2ME2 to MDA-MB-231 cells and hypoxic conditioning in MCF7 cells. A full colour version of this figure is available at https://doi. org/10.1530/ERC-19-0054.

BCSLCs. As a key transcription factor, HIF- $1 \alpha$ can regulate many downstream target genes by binding to HREs on their promoter. However, whether HIF- $1 \alpha$ can directly regulate the functional level of $\alpha$-SMA via transcriptional modulation is still unclear.

\section{PEDF inhibits breast tumor growth by suppressing the formation of heterogeneous vascularity}

Based on the above results, we believe that the development of new antiangiogenic therapeutic agents is urgently needed for breast cancer treatment. PEDF is a kind of endogenous multifunctional glycoprotein with prominent antiangiogenic effects (Ek \& Dass et al. 2006, Zhang et al. 2006, Yang et al. 2009). Previous studies have reported that PEDF can inhibit vasculogenic mimicry in melanoma (Orgaz et al. 2009). However, the exact mechanism has not been not thoroughly elucidated. Additionally, the effect of PEDF on heterogeneous vascularity in breast cancer has not yet been reported.

Our results showed high PEDF expression in MCF7 cells and significantly lower PEDF expression in MDA-MB-231 cells (Fig. 6A). To explore whether high PEDF inhibits the tube-forming ability of MCF7 cells, we knocked down PEDF in MCF7 cells with siRNA and assessed their capability of tube formation (Fig. 6C). Tube formation was lower in MDA-MB-231 cells transfected with Ad-PEDF than in cells transfected with Ad-GFP (Fig. 6B). Next, we conducted 3D in vitro experiments and found that PEDF can dramatically disrupt tube formation by HUVECs and MDA-MB-231 cells (Fig. 6D).

In vivo, we measured tumor volume every 3 days and found that tumor size in the PEDF group was obviously smaller than that in the control group (Fig. 6F and G). One mouse in the PBS group was euthanized on days 27, 31, 38 and 41, while one mouse in the PEDF group was euthanized on days 38 and 42 . By day 43 of the experiment, we found that PEDF could effectively improve the survival rate (Fig. $6 \mathrm{H}$ ). We collected further tumors at different time points by CD31/PAS staining. Consistent with the in vitro results, PEDF could suppress blood vessel formation and vasculogenic mimicry (Fig. 6I).

These results indicated that the endogenous factor PEDF can effectively inhibit tumor growth by suppressing heterogeneous vasculogenesis. Mechanistically, the effect is likely dependent on HIF-1 $\alpha / \alpha$-SMA (Fig. $6 \mathrm{~J}$ and Supplementary Fig. 7).

Hence, we propose a molecule, PEDF, that can effectively suppress angiogenesis and significantly inhibit heterogeneous vasculogenesis, opening new opportunities for the clinical treatment of breast cancer.

\section{Mechanism summary}

In breast cancer, the antiangiogenic drug sorafenib can decrease MVD by targeting ECs. However, this therapeutic 
A

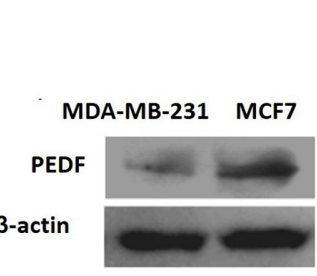

B

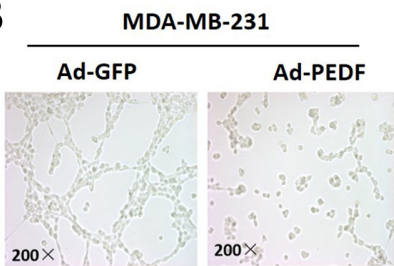

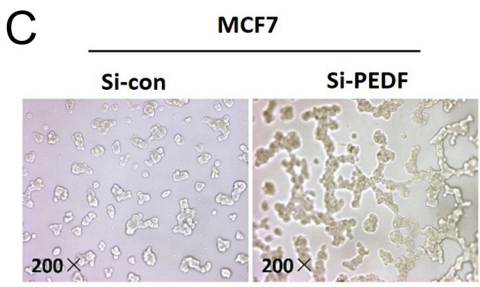

$200 x$

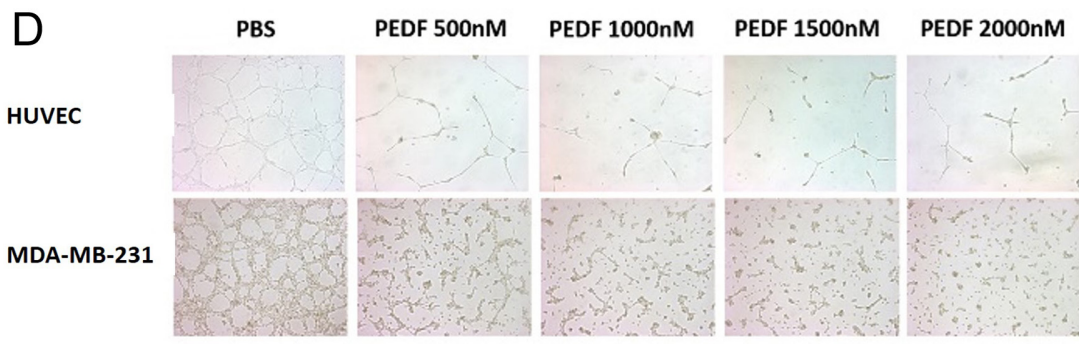

E

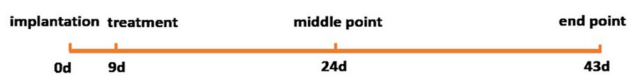

\section{F}
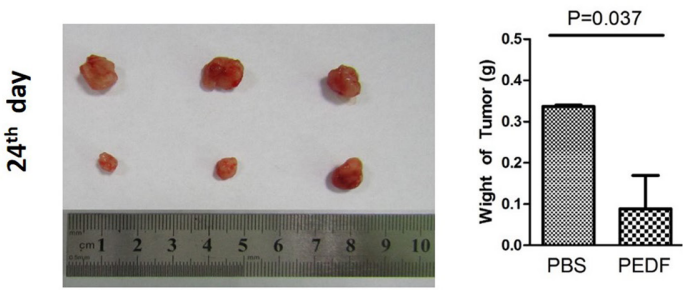

G
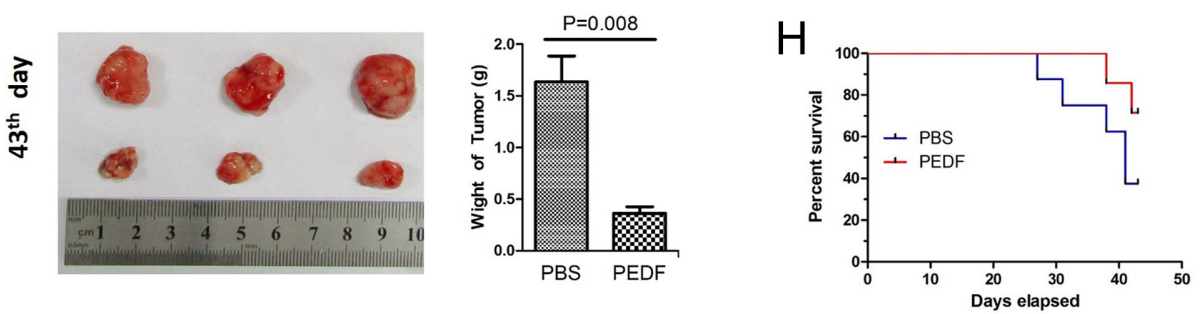

I
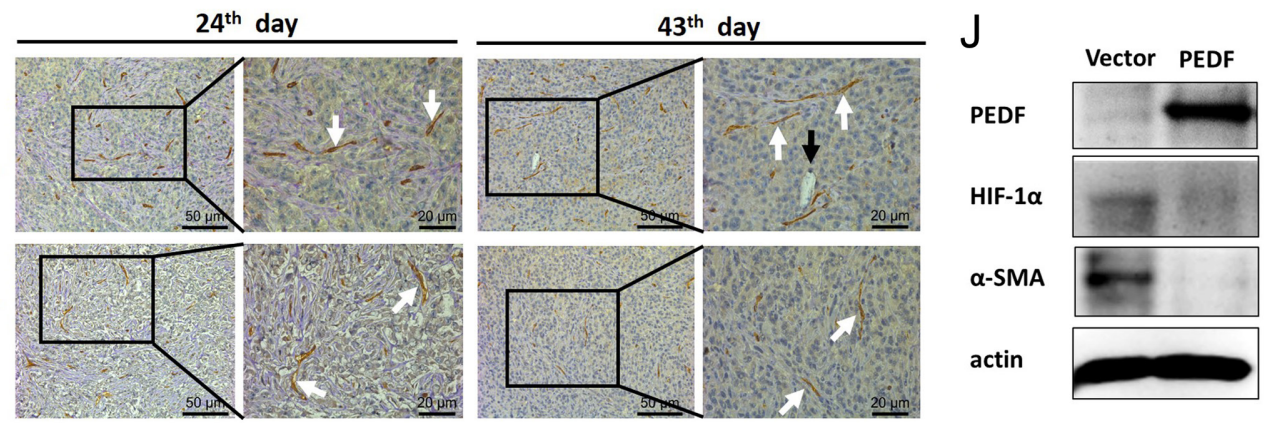

\section{Figure 6}

Effect of PEDF on breast cancer in vivo and in vitro. (A) Western blot analysis for PEDF expression in breast cancer cells MDA-MB-231 and MCF7. $\beta$-Actin was used as a loading control. (B) Representative micrographs showing the formation of capillary-like structures in Matrigel by MDA-MB-231 cells transfected with Ad-GFP and Ad-PEDF. (C) Verification of the effect of siRNA-mediated interference of PEDF promoting tube formation by MCF7 cells. (D) HUVECS and MDA-MB-231 cells were seeded into 24-well plates coated with Matrigel. After $8 \mathrm{~h}$, the cells were treated with different doses of PEDF. Formation of tube-like structures was examined by phase contrast microscopy $12 \mathrm{~h}$ later. (Objective magnification, $\times 200$ ). (E) Schematic representation showing the strategy for animal experiments. ( $F$ and G) Tumor size in mice bearing MDA-MB-231 breast cancer cells treated with PBS ( $n=3$ ) and PEDF $(n=3)$ at two time points. $(H)$ Survival analysis of the PBS and PEDF groups. Kaplan-Meier actuarial survival curves were used to compare the PBS group $(n=7)$ with the PEDF group $(n=7)$. The PEDF group tended to have a higher overall survival than the PBS group. (I) Paraffin sections of tumors at two time points were subjected to CD31/PAS double staining. White arrow shows CD31+ECs. Black arrow shows CD31-/PAS+ structures formed by vasculogenic mimicry with red blood cells. (J) HIF-1 $\alpha$ and $\alpha$-SMA expression by Western blot analysis in MDA-MB-231 cells transfected with vector and PEDF. A full colour version of this figure is available at https://doi.org/10.1530/ERC-19-0054. 
strategy may lead to aggravated anoxia in the tumor (Conley et al. 2012). The hypoxic environment will promote the expression of HIF-1 $\alpha$ as an adaptive response. HIF- $1 \alpha$ can subsequently increase the proportion of BCSLCs and enhance the expression of $\alpha$-SMA by directly binding to the HRE on the ACTA2 promoter. The increased expression of functional $\alpha$-SMA enables BCSLCs to participate in the heterogeneous vasculogenesis. PEDF can suppress both heterogeneous vasculogenesis and traditional angiogenesis by targeting BCSLCs and ECs to effectively starve tumors (Supplementary Fig. 8).

\section{Discussion}

Heterogeneous vascularity was once considered a possible reason for the poor curative effects of antiangiogenic therapy. The molecular basis underlying the pathogenesis of heterogeneous vascularity in breast cancer is not completely understood. The present study, for the first time, demonstrated that only BCSLCs have the capability to participate in the formation of blood vessels. Mechanistically, we have illustrated that (1) $\alpha$-SMA, a marker of EMT and pericytes, was a key functional molecule contributing to capillary structure formation by BCSLCs; (2) HIF- $1 \alpha$ increased BCSLC population and enhanced the mRNA and protein levels of $\alpha$-SMA by directly binding to the HRE on the ACTA2 promoter; (3) the endogenous angiogenesis inhibitor PEDF could inhibit not only traditional angiogenesis but also heterogeneous vasculogenesis by downregulating HIF- $1 \alpha$ and $\alpha$-SMA in breast cancer. Our study not only suggested a new mechanism in which HIF-1 $\alpha$-driven BCSLCs participate in heterogeneous vascularity in tumors, but also provided an effective approach to suppress these specific vessels. These findings further enrich our knowledge on the properties of heterogeneous vascularity and provide a promising candidate drug for the treatment of breast cancer.

Previously, tumor angiogenesis was considered to mainly arise from normal blood vessel sprouting. However, accumulated evidence indicates that vascular perfusion is temporally and spatially heterogeneous and involves cancer cells participating in various vessel-like structures including co-opted vessels, mosaic vessels, and tubular structures formed by vasculogenic mimicry (Jain 1988), suggesting that targeting ECs alone is not sufficient for effective tumor control. We have detected a variety of microcirculation models including vasculogenic mimicry and mosaic vasculogenesis in TNBC specimens (Fig. 3A). In addition, we provided evidence both in vitro and in vivo that sorafenib could inhibit tube formation or vascularization by ECs but not by breast cancer cells (Supplementary Fig. 1). However, what determines the features and mechanisms of vascular formation by these tumor cells remained unknown. Previously, highly malignant and aggressive tumor cells were shown to participate in vasculogenic mimicry by expressing endothelial maker VE-cadherin or endothelial phenotypes (Hendrix et al. 2000). Elvin Wagenblast proposed that enforced expression of SERPINE2 and SLPI in human breast cancer cell lines also programmed them for vascular mimicry (Wagenblast et al. 2015). Moreover, recent studies have found that EMT endows cancer cells with pericyte properties and is indispensable for vascular stabilization and sustained tumor growth (Shenoy et al. 2016). In our study, we confirmed that only the stem-like ALDH1+ tumor cells in breast cancer had tube-forming ability. Although the ALDH1- cells isolated from MDA-MB-231 cells expressed most mesenchymal markers, they could not form tube-like structures (Fig. 1).

The perivascular region is recognized as a niche for stem-like cancer cells in several head and neck cancers (Ritchie \& Nor 2013). Vascular cells including ECs and pericytes can help maintain CSC phenotypes in a paracrine manner. However, it was unknown how CSCs contribute to tumor vessel formation. Recent studies have proposed that CSCs have the potential to generate pericytes and ECs to form blood vessels in breast cancer and glioblastoma (Wang et al. 2010, Cheng et al. 2013, Tang et al. 2014). These studies showed that CSCs had the ability to contribute to the tumor vasculature formation by promoting EC and pericyte differentiation through the production of directional differentiation factors. Nevertheless, our data suggest for the first time that tumor cells involved in heterogeneous vasculogenesis in breast cancer possess stem-like properties owing to their ability to express $\alpha$-SMA without differentiation. Furthermore, we confirmed that $\alpha$-SMA plays an important role in the formation of vessel-like structures by BCSLCs (Figs 2 and 3).

$\alpha$-SMA has been recognized as an important marker for pericytes, EMT and cancer-associated fibroblasts (CAFs). Tumor cells undergoing EMT or CAFs are reported to promote tumor metastasis (Kalluri 2016, Shenoy et al. 2016). However, the functions of $\alpha$-SMA have not been thoroughly investigated in these cells. In this study, we provide evidence that $\alpha$-SMA is a crucial functional molecule enabling the participation of BCSLCs in heterogeneous vasculogenesis in vivo and in vitro (Figs 2 and 3). However, the regulatory mechanism of $\alpha$-SMA 
is unclear at present. The suppression of Flk-1 has been reported to be associated with a corresponding reduction in $\alpha$-SMA expression (Francescone et al. 2012). Phosphate can decrease the level of $\alpha$-SMA in vascular smooth muscle cells (VSMCs) via the Wnt/ $\beta$-catenin pathway (He et al. 2018). Our recent study showed that high glucose increased the expression of the mesenchymal marker $\alpha$-SMA in Müller cells (Zhou et al. 2017). In this article, we demonstrated for the first time that HIF-1 $\alpha$, an important transcription factor that can regulate many target genes in hypoxia, upregulates the expression of $\alpha$-SMA by directly binding to the HRE on the ACTA2 promoter (Fig. 4).

The lack of effect on BCSLC-derived vessels might be the reason for the poor outcomes of antiangiogenic therapy. In November 2011, the FDA announced the cancelation of bevacizumab (Avastin $\AA$ ) use for breast cancer. The results of a phase III clinical trial on sorafenib for HER-2-negative breast cancer showed that sorafenib combined with capecitabine cannot improve progressionfree survival relative to placebo but results in harmful side effects (Bergh et al. 2012, Bertucci et al. 2016, Ribatti et al. 2016). The therapeutic strategy may lead to aggravated anoxia in the tumor. Hypoxia plays a critical role in the evolution of the tumor stromal microenvironment and can inhibit tumor cell differentiation and promote CSC maintenance (Ezashi \& Das et al. 2005, Gustafsson et al. 2005). Accumulating evidence shows that culturing glioma cells in $2 \%$ oxygen rather than in standard $20 \%$ oxygen increases the $\mathrm{CD} 133^{+}$cell population and enhances tumor sphere formation of stem cell populations by activating HIF-1 $\alpha$ (Morrison et al. 2000, Blazek \& Foutch et al. 2007). Knockdown of HIF- $1 \alpha$ abrogates the expansion of CD133+ GSCs under hypoxia (Soeda et al. 2009). Consistent with these reports, we found that HIF- $1 \alpha$ can increase the proportion of BCSLCs and induce capillary structure formation (Fig. 5). Therefore, we inferred that BCSLCs participate in tumor vascular formation in a HIF- $1 \alpha / \alpha$-SMA-dependent manner, which is insensitive to sorafenib. However, PEDF can significantly inhibit this pathway (Supplementary Fig. 8).

PEDF is an endogenous antiangiogenic factor that plays an important role in inhibiting tumor growth and metastasis (Yang et al. 2009), suppressing EMT in tumor cells (Zhang et al. 2017), and inducing tumor cell apoptosis (Li et al. 2014). PEDF can inhibit vasculogenic mimicry in melanoma (Orgaz et al. 2009). Our recent study demonstrated that PEDF can inhibit HIF- $1 \alpha$ expression in nasopharyngeal carcinoma CNE- 2 cells (Xu et al. 2011). The present study demonstrated for the first time that PEDF could inhibit vasculogenic mimicry by downregulating HIF-1 $\alpha$ and BCSLC proportions in breast cancer. These results suggested that PEDF might be a powerful antiangiogenic drug because of its dual effects on angiogenesis and heterogeneous vasculogenesis in breast cancer.

In summary, we identified a critical role of BCSLCs in heterogeneous vasculogenesis in tumors. Activation of HIF-1 $\alpha$ enhanced BCSLC proportion and $\alpha$-SMA expression, and heterogeneous vasculatures formed by BCSLCs might be the reason for the poor curative effects of sorafenib. Mechanistically, HIF- $1 \alpha / \alpha$-SMA could potentially be exploited as novel therapeutic targets for the treatment of heterogeneous tumor vascularity. Additionally, PEDF may be a promising candidate for the treatment of breast cancer.

\section{Supplementary materials}

This is linked to the online version of the paper at https://doi.org/10.1530/ ERC-19-0054.

Declaration of interest

The authors declare that there is no conflict of interest that could be perceived as prejudicing the impartiality of the research reported.

\section{Funding}

This study was supported by the National Nature Science Foundation of China, Grant Number: 81872165, 81572342, 81770808, 81471033, 81600641, 81370945, 81570871, 81570764, 81701414, 81871211, 81502507; National Key R\&D Program of China, grant numbers: 2018YFA0800403; Guangdong Provincial Key R\&D Program grant numbers: 2018B030337001; National Key Sci-Tech Special Project of China, Grant Number: 2013ZX09102-053, 2015GKS-355; Key Project of Nature Science Foundation of Guangdong Province, China, Grant Number: 2015A030311043, 2016A030311035; Guangdong Natural Science Fund, Grant Number: 2014A020212023, 2014A030313073, 2015A030313029, 2015A030313103; Guangdong Science Technology Project, Grant Number: 2017A020215075, 2015B090903063; Initiate Research Funds for the Central Universities of China (Youth Program), Grant Number: 14ykpy05, 16ykpy24. Key Sci-tech Research Project of Guangzhou Municipality, China, Grant Number: 201508020033, 201510010052, 201707010084, 201803010017; Pearl River Nova Program of Guangzhou Municipality, China, Grant number: 201610010186; 2017 and 2019 Milstein Medical Asian American Partnership Foundation Research Project Award in Translational Medicine.

\section{Author contribution statement}

All authors have contributed significantly to this manuscript and each author has contributed to the manuscript as follows: Yuling Mao and Guoquan Gao designed the project. Yuling Mao, Liuqing Zhu and Chuanghua Luo collected clinical samples and performed the histology experiments and analyzed the data. Yuling Mao and Liuqing Zhu performed mainly cell experiments and immunofluorescent assay, as well as analyzed the results. Yuling Mao and Weiwei Qi did the PEDF protein production and analyzed the data. Yuling Mao and Zhijian Huang 
performed the tube-fomation assay and analyzed the data. Zhijian Huang carried out the additional experiments. Xia Yang, Guoquan Gao and Yuling Mao wrote the manuscript. Weiwei Qi, Zhonghan Yang and Ti Zhou revised the manuscript.

\section{Acknowledgements}

The authors thank Prof. Dr Erwei Song for donating the clinical samples. And they thank Profs Xiaoming Song and Hailin Tang for donating the clinical tissue sections.

\section{References}

Adjei AA, Blumenschein Jr GR, Mandrekar S, Hillman S, Gatzemeier U \& Heigener D 2011 Long-term safety and tolerability of sorafenib in patients with advanced non-small-cell lung cancer: a case-based review. Clinical Lung Cancer 12 212-217. (https://doi.org/10.1016/j. cllc.2011.03.021)

Al-Hajj M, Wicha MS, Benito-Hernandez A, Morrison SJ \& Clarke MF 2003 Prospective identification of tumorigenic breast cancer cells. PNAS 100 3983-3988. (https://doi.org/10.1073/pnas.0530291100)

Azzariti A, Mancarella S, Porcelli L, Quatrale AE, Caligiuri A, Lupo L, Dituri F \& Giannelli G 2016 Hepatic stellate cells induce hepatocellular carcinoma cell resistance to sorafenib through the laminin-332/alpha3 integrin axis recovery of focal adhesion kinase ubiquitination. Hepatology 64 2103-2117. (https://doi.org/10.1002/ hep.28835)

Basu GD, Liang WS, Stephan DA, Wegener LT, Conley CR, Pockaj BA \& Mukherjee P 2006 A novel role for cyclooxygenase-2 in regulating vascular channel formation by human breast cancer cells. Breast Cancer Research 8 R69. (https://doi.org/10.1186/bcr1626)

Bergh J, Bondarenko IM, Lichinitser MR, Liljegren A, Greil R, Voytko NL, Makhson AN, Cortes J, Lortholary A, Bischoff J, et al. 2012 First-line treatment of advanced breast cancer with sunitinib in combination with docetaxel versus docetaxel alone: results of a prospective, randomized phase III study. Journal of Clinical Oncology 30 921-929. (https://doi.org/10.1200/JCO.2011.35.7376)

Bertucci F, Fekih M, Autret A, Petit T, Dalenc F, Levy C, Romieu G, Bonneterre J, Ferrero JM, Kerbrat P, et al. 2016 Bevacizumab plus neoadjuvant chemotherapy in patients with HER2-negative inflammatory breast cancer (BEVERLY-1): a multicentre, single-arm, phase 2 study. Lancet: Oncology 17 600-611. (https://doi.org/10.1016/ S1470-2045(16)00011-5)

Blazek ER, Foutch JL \& Maki G 2007 Daoy medulloblastoma cells that express CD133 are radioresistant relative to CD133- cells, and the CD133+ sector is enlarged by hypoxia. International Journal of Radiation Oncology, Biology, Physics 67 1-5. (https://doi.org/10.1016/i. ijrobp.2006.09.037)

Chen HA, Kuo TC, Tseng CF, Ma JT, Yang ST, Yen CJ, Yang CY, Sung SY \& Su JL 2016 Angiopoietin-like protein 1 antagonizes MET receptor activity to repress sorafenib resistance and cancer stemness in hepatocellular carcinoma. Hepatology 64 1637-1651. (https://doi. org/10.1002/hep.28773)

Cheng L, Huang Z, Zhou W, Wu Q, Donnola S, Liu JK, Fang X, Sloan AE, Mao Y, Lathia JD, et al. 2013 Glioblastoma stem cells generate vascular pericytes to support vessel function and tumor growth. Cell 153 139-152. (https://doi.org/10.1016/j. cell.2013.02.021)

Conley SJ, Gheordunescu E, Kakarala P, Newman B, Korkaya H, Heath AN, Clouthier SG \& Wicha MS 2012 Antiangiogenic agents increase breast cancer stem cells via the generation of tumor hypoxia. PNAS 109 2784-2789. (https://doi.org/10.1073/ pnas.1018866109) di Tomaso E, Capen D, Haskell A, Hart J, Logie JJ, Jain RK, McDonald DM, Jones R \& Munn LL 2005 Mosaic tumor vessels: cellular basis and ultrastructure of focal regions lacking endothelial cell markers. Cancer Research 65 5740-5749. (https://doi. org/10.1158/0008-5472.CAN-04-4552)

Du J, Sun B, Zhao X, Gu Q, Dong X, Mo J, Sun T, Wang J, Sun R \& Liu Y 2014 Hypoxia promotes vasculogenic mimicry formation by inducing epithelial-mesenchymal transition in ovarian carcinoma. Gynecologic Oncology 133 575-583. (https://doi.org/10.1016/j. ygyno.2014.02.034)

Ek ET, Dass CR \& Choong PF 2006 Pigment epithelium-derived factor: a multimodal tumor inhibitor. Molecular Cancer Therapeutics 5 16411646. (https://doi.org/10.1158/1535-7163.MCT-06-0107)

El Hallani S, Boisselier B, Peglion F, Rousseau A, Colin C, Idbaih A, Marie Y, Mokhtari K, Thomas JL, Eichmann A, et al. 2010 A new alternative mechanism in glioblastoma vascularization: tubular vasculogenic mimicry. Brain 133 973-982. (https://doi.org/10.1093/ brain/awq044)

Ezashi T, Das P \& Roberts RM 2005 Low O2 tensions and the prevention of differentiation of hES cells. PNAS 102 4783-4788. (https://doi. org/10.1073/pnas.0501283102)

Folkman J 2002 Role of angiogenesis in tumor growth and metastasis. Seminars in Oncology 29 (6 Supplement 16) 15-18. (https://doi. org/10.1053/sonc.2002.37263)

Francescone R, Scully S, Bentley B, Yan W, Taylor SL, Oh D, Moral L \& Shao R 2012 Glioblastoma-derived tumor cells induce vasculogenic mimicry through Flk-1 protein activation. Journal of Biological Chemistry 287 24821-24831. (https://doi.org/10.1074/jbc. M111.334540)

Galli R, Binda E, Orfanelli U, Cipelletti B, Gritti A, De Vitis S, Fiocco R, Foroni C, Dimeco F \& Vescovi A 2004 Isolation and characterization of tumorigenic, stem-like neural precursors from human glioblastoma. Cancer Research 64 7011-7021. (https://doi. org/10.1158/0008-5472.CAN-04-1364)

Ginestier C, Hur MH, Charafe-Jauffret E, Monville F, Dutcher J, Brown M, Jacquemier J, Viens P, Kleer CG, Liu S, et al. 2007 ALDH1 is a marker of normal and malignant human mammary stem cells and a predictor of poor clinical outcome. Cell Stem Cell 1 555-567. (https://doi.org/10.1016/j.stem.2007.08.014)

Gradishar WJ 2012 Sorafenib in locally advanced or metastatic breast cancer. Expert Opinion on Investigational Drugs 21 1177-1191. (https:// doi.org/10.1517/13543784.2012.689824)

Gustafsson MV, Zheng X, Pereira T, Gradin K, Jin S, Lundkvist J, Ruas JL, Poellinger L, Lendahl U \& Bondesson M 2005 Hypoxia requires notch signaling to maintain the undifferentiated cell state. Developmental Cell 9 617-628. (https://doi.org/10.1016/j.devcel.2005.09.010)

Hanahan D \& Weinberg RA 2011 Hallmarks of cancer: the next generation. Cell 144 646-674. (https://doi.org/10.1016/j. cell.2011.02.013)

He F, Wang H, Ren WY, Ma Y, Liao YP, Zhu JH, Cui J, Deng ZL, Su YX, Gan H, et al. 2018 BMP9/COX-2 axial mediates high phosphateinduced calcification in vascular smooth muscle cells via Wnt/betacatenin pathway. Journal of Cellular Biochemistry 119 2851-2863. (https://doi.org/10.1002/jcb.26460)

Hendrix MJ, Seftor EA, Kirschmann DA \& Seftor RE 2000 Molecular biology of breast cancer metastasis. Molecular expression of vascular markers by aggressive breast cancer cells. Breast Cancer Research 2 417-422. (https://doi.org/10.1186/bcr88)

Hendrix MJ, Seftor EA, Hess AR \& Seftor RE 2003 Vasculogenic mimicry and tumour-cell plasticity: lessons from melanoma. Nature Reviews: Cancer 3 411-421. (https://doi.org/10.1038/nrc1092)

Hong H, Zhou T, Fang S, Jia M, Xu Z, Dai Z, Li C, Li S, Li L, Zhang T, et al. 2014 Pigment epithelium-derived factor (PEDF) inhibits breast cancer metastasis by down-regulating fibronectin. Breast Cancer Research and Treatment 148 61-72. (https://doi.org/10.1007/s10549014-3154-9) (c) 2020 Society for Endocrinology Published by Bioscientifica Ltd. Printed in Great Britain 
Hutson TE, Bellmunt J, Porta C, Szczylik C, Staehler M, Nadel A, Anderson S, Bukowski R, Eisen T, Escudier B, et al. 2010 Long-term safety of sorafenib in advanced renal cell carcinoma: follow-up of patients from phase III TARGET. European Journal of Cancer 462432 2440. (https://doi.org/10.1016/j.ejca.2010.06.121)

Jaffe EA, Nachman RL, Becker CG \& Minick CR 1973 Culture of human endothelial cells derived from umbilical veins. Identification by morphologic and immunologic criteria. Journal of Clinical Investigation 52 2745-2756. (https://doi.org/10.1172/JCI107470)

Jain RK 1988 Determinants of tumor blood flow: a review. Cancer Research 48 2641-2658.

Kalluri R 2016 The biology and function of fibroblasts in cancer. Nature Reviews: Cancer 16 582-598. (https://doi.org/10.1038/nrc.2016.73)

Li L, Yao YC, Fang SH, Ma CQ, Cen Y, Xu ZM, Dai ZY, Li C, Li S, Zhang T, et al. 2014 Pigment epithelial-derived factor (PEDF)triggered lung cancer cell apoptosis relies on p53 protein-driven Fas ligand (Fas-L) up-regulation and Fas protein cell surface translocation. Journal of Biological Chemistry 289 30785-30799. (https://doi.org/10.1074/jbc.M114.590000)

Liang Y, Zheng T, Song R, Wang J, Yin D, Wang L, Liu H, Tian L, Fang X, Meng X, et al. 2013 Hypoxia-mediated sorafenib resistance can be overcome by EF24 through von Hippel-Lindau tumor suppressor-dependent HIF-1alpha inhibition in hepatocellular carcinoma. Hepatology 57 1847-1857. (https://doi.org/10.1002/ hep.26224)

Llovet JM, Ricci S, Mazzaferro V, Hilgard P, Gane E, Blanc JF, de Oliveira AC, Santoro A, Raoul JL, Forner A, et al. 2008 Sorafenib in advanced hepatocellular carcinoma. New England Journal of Medicine 359 378-390. (https://doi.org/10.1056/NEJMoa0708857)

Lu H, Samanta D, Xiang L, Zhang H, Hu H, Chen I, Bullen JW \& Semenza GL 2015 Chemotherapy triggers HIF-1-dependent glutathione synthesis and copper chelation that induces the breast cancer stem cell phenotype. PNAS 112 E4600-E4609. (https://doi. org/10.1073/pnas.1513433112)

Maniotis AJ, Folberg R, Hess A, Seftor EA, Gardner LM, Pe'er J, Trent JM, Meltzer PS \& Hendrix MJ 1999 Vascular channel formation by human melanoma cells in vivo and in vitro: vasculogenic mimicry. American Journal of Pathology 155 739-752. (https://doi.org/10.1016/ S0002-9440(10)65173-5)

Morrison SJ, Csete M, Groves AK, Melega W, Wold B \& Anderson DJ 2000 Culture in reduced levels of oxygen promotes clonogenic sympathoadrenal differentiation by isolated neural crest stem cells. Journal of Neuroscience 20 7370-7376. (https://doi.org/10.1523/ JNEUROSCI.20-19-07370.2000)

Nakanishi T, Chumsri S, Khakpour N, Brodie AH, Leyland-Jones B, Hamburger AW, Ross DD \& Burger AM 2010 Side-population cells in luminal-type breast cancer have tumour-initiating cell properties, and are regulated by HER2 expression and signalling. British Journal of Cancer 102 815-826. (https://doi.org/10.1038/sj.bjc.6605553)

Orgaz JL, Ladhani O, Hoek KS, Fernandez-Barral A, Mihic D, Aguilera O, Seftor EA, Bernad A, Rodriguez-Peralto JL, Hendrix MJ, et al. 2009 Loss of pigment epithelium-derived factor enables migration, invasion and metastatic spread of human melanoma. Oncogene 28 4147-4161. (https://doi.org/10.1038/onc.2009.284)

Rayson D, Vantyghem SA \& Chambers AF 1999 Angiogenesis as a target for breast cancer therapy. Journal of Mammary Gland Biology and Neoplasia 4 415-423. (https://doi.org/10.1023/a:1018774618873)

Ribatti D, Nico B, Ruggieri S, Tamma R, Simone G \& Mangia A 2016 Angiogenesis and antiangiogenesis in triple-negative breast cancer. Translational Oncology 9 453-457. (https://doi.org/10.1016/j. tranon.2016.07.002)

Ritchie KE \& Nor JE 2013 Perivascular stem cell niche in head and neck cancer. Cancer Letters 338 41-46. (https://doi.org/10.1016/j. canlet.2012.07.025)

Rudalska R, Dauch D, Longerich T, McJunkin K, Wuestefeld T, Kang TW, Hohmeyer A, Pesic M, Leibold J, von Thun A, et al. 2014 In vivo
RNAi screening identifies a mechanism of sorafenib resistance in liver cancer. Nature Medicine 20 1138-1146. (https://doi.org/10.1038/ nm.3679)

Sharma N, Seftor RE, Seftor EA, Gruman LM, Heidger Jr PM, Cohen MB, Lubaroff DM \& Hendrix MJ 2002 Prostatic tumor cell plasticity involves cooperative interactions of distinct phenotypic subpopulations: role in vasculogenic mimicry. Prostate 50 189-201. (https://doi.org/10.1002/pros.10048)

Shenoy AK, Jin Y, Luo H, Tang M, Pampo C, Shao R, Siemann DW, Wu L, Heldermon CD, Law BK, et al. 2016 Epithelial-tomesenchymal transition confers pericyte properties on cancer cells. Journal of Clinical Investigation 126 4174-4186. (https://doi. org/10.1172/JCI86623)

Shirakawa K, Tsuda H, Heike Y, Kato K, Asada R, Inomata M, Sasaki H, Kasumi F, Yoshimoto M, Iwanaga T, et al. 2001 Absence of endothelial cells, central necrosis, and fibrosis are associated with aggressive inflammatory breast cancer. Cancer Research 61 445-451.

Singh SK, Clarke ID, Terasaki M, Bonn VE, Hawkins C, Squire J \& Dirks PB 2003 Identification of a cancer stem cell in human brain tumors. Cancer Research 63 5821-5828.

Soeda A, Park M, Lee D, Mintz A, Androutsellis-Theotokis A, McKay RD, Engh J, Iwama T, Kunisada T, Kassam AB, et al. 2009 Hypoxia promotes expansion of the CD133-positive glioma stem cells through activation of HIF-1alpha. Oncogene 28 3949-3959. (https:// doi.org/10.1038/onc.2009.252)

Sun B, Zhang D, Zhang S, Zhang W, Guo H \& Zhao X 2007 Hypoxia influences vasculogenic mimicry channel formation and tumor invasion-related protein expression in melanoma. Cancer Letters $\mathbf{2 4 9}$ 188-197. (https://doi.org/10.1016/j.canlet.2006.08.016)

Sun T, Zhao N, Zhao XL, Gu Q, Zhang SW, Che N, Wang XH, Du J, Liu YX \& Sun BC 2010 Expression and functional significance of Twist1 in hepatocellular carcinoma: its role in vasculogenic mimicry. Hepatology 51 545-556. (https://doi.org/10.1002/hep.23311)

Sun W, Shen ZY, Zhang H, Fan YZ, Zhang WZ, Zhang JT, Lu XS \& Ye C 2012 Overexpression of HIF-1alpha in primary gallbladder carcinoma and its relation to vasculogenic mimicry and unfavourable prognosis. Oncology Reports 27 1990-2002. (https://doi.org/10.3892/ or.2012.1746)

Takubo K, Goda N, Yamada W, Iriuchishima H, Ikeda E, Kubota Y, Shima H, Johnson RS, Hirao A, Suematsu M, et al. 2010 Regulation of the HIF-1alpha level is essential for hematopoietic stem cells. Cell Stem Cell 7 391-402. (https://doi.org/10.1016/j.stem.2010.06.020)

Tang W, Yu F, Yao H, Cui X, Jiao Y, Lin L, Chen J, Yin D, Song E \& Liu Q 2014 miR-27a regulates endothelial differentiation of breast cancer stem like cells. Oncogene 33 2629-2638. (https://doi. org/10.1038/onc.2013.214)

Torre LA, Bray F, Siegel RL, Ferlay J, Lortet-Tieulent J \& Jemal A 2015 Global cancer statistics, 2012. CA: A Cancer Journal for Clinicians 65 87-108. (https://doi.org/10.3322/caac.21262)

Wagenblast E, Soto M, Gutierrez-Angel S, Hartl CA, Gable AL, Maceli AR, Erard N, Williams AM, Kim SY, Dickopf S, et al. 2015 A model of breast cancer heterogeneity reveals vascular mimicry as a driver of metastasis. Nature 520 358-362. (https://doi.org/10.1038/ nature14403)

Wang R, Chadalavada K, Wilshire J, Kowalik U, Hovinga KE, Geber A, Fligelman B, Leversha M, Brennan C \& Tabar V 2010 Glioblastoma stem-like cells give rise to tumour endothelium. Nature 468 829-833. (https://doi.org/10.1038/nature09624)

Wilhelm SM, Adnane L, Newell P, Villanueva A, Llovet JM \& Lynch M 2008 Preclinical overview of sorafenib, a multikinase inhibitor that targets both Raf and VEGF and PDGF receptor tyrosine kinase signaling. Molecular Cancer Therapeutics 7 3129-3140. (https://doi. org/10.1158/1535-7163.MCT-08-0013)

Xu Z, Fang S, Zuo Y, Zhang Y, Cheng R, Wang Q, Yang Z, Cai W, Ma J, Yang $X$, et al. 2011 Combination of pigment epithelium-derived factor with radiotherapy enhances the antitumor effects on https://erc.bioscientifica.com

https://doi.org/10.1530/ERC-19-0054
C) 2020 Society for Endocrinology Published by Bioscientifica Ltd. Printed in Great Britain 
nasopharyngeal carcinoma by downregulating vascular endothelial growth factor expression and angiogenesis. Cancer Science 102 17891798. (https://doi.org/10.1111/j.1349-7006.2011.02013.x)

Yang H, Cheng R, Liu G, Zhong Q, Li C, Cai W, Yang Z, Ma J, Yang X \& Gao G 2009 PEDF inhibits growth of retinoblastoma by antiangiogenic activity. Cancer Science 100 2419-2425. (https://doi. org/10.1111/j.1349-7006.2009.01332.x)

Yu JL, Rak JW, Carmeliet P, Nagy A, Kerbel RS \& Coomber BL 2001 Heterogeneous vascular dependence of tumor cell populations. American Journal of Pathology 158 1325-1334. (https://doi. org/10.1016/S0002-9440(10)64083-7)

Zhang SX, Wang JJ, Gao G, Shao C, Mott R \& Ma JX 2006 Pigment epithelium-derived factor (PEDF) is an endogenous antiinflammatory factor. FASEB Journal 20 323-325. (https://doi. org/10.1096/fj.05-4313fje)

Zhang T, Yin P, Zhang Z, Xu B, Che D, Dai Z, Dong C, Jiang P, Hong H, Yang Z, et al. 2017 Deficiency of pigment epithelium-derived factor in nasopharyngeal carcinoma cells triggers the epithelialmesenchymal transition and metastasis. Cell Death and Disease 8 e2838. (https://doi.org/10.1038/cddis.2017.114)

Zhong H, De Marzo AM, Laughner E, Lim M, Hilton DA, Zagzag D, Buechler P, Isaacs WB, Semenza GL \& Simons JW 1999 Overexpression of hypoxia-inducible factor 1alpha in common human cancers and their metastases. Cancer Research 59 $5830-5835$.

Zhong Y, Shen S, Zhou Y, Mao F, Guan J, Lin Y, Xu Y \& Sun Q 2014 ALDH1 is a better clinical indicator for relapse of invasive ductal breast cancer than the CD44+/CD24- phenotype. Medical Oncology 31 864. (https://doi.org/10.1007/s12032-014-0864-0)

Zhou T, Che D, Lan Y, Fang Z, Xie J, Gong H, Li C, Feng J, Hong H, Qi W, et al. 2017 Mesenchymal marker expression is elevated in Muller cells exposed to high glucose and in animal models of diabetic retinopathy. Oncotarget 8 4582-4594. (https://doi. org/10.18632/oncotarget.13945)

Received in final form 14 October 2019

Accepted 7 November 2019

Accepted Manuscript published online 7 November 2019 (c) 2020 Society for Endocrinology Published by Bioscientifica Ltd. Printed in Great Britain 